\title{
Ocean Circulation and Water Mass Characteristics around the Galápagos Archipelago Simulated by a Multiscale Nested Ocean Circulation Model
}

\author{
Yanyun Liu, ${ }^{1,2,3}$ Lian Xie, ${ }^{1}$ John M. Morrison, ${ }^{4}$ Dan Kamykowski, ${ }^{1}$ and William V. Sweet ${ }^{1,5}$ \\ ${ }^{1}$ Department of Marine, Earth, and Atmospheric Sciences, North Carolina State University, Raleigh, NC 27695-8208, USA \\ ${ }^{2}$ Cooperative Institute for Marine and Atmospheric Studies, University of Miami, Miami, FL 33129-1098, USA \\ ${ }^{3}$ Atlantic Oceanographic and Meteorological Laboratory, NOAA, 4301 Rickenbacker Causeway, Miami, FL 33129-1026, USA \\ ${ }^{4}$ Department of Physics and Physical Oceanography, University of North Carolina at Wilmington, Wilmington, \\ NC 28403-5606, USA \\ ${ }^{5}$ National Ocean Service, NOAA, Center for Operational Oceanographic Products and Services, Silver Spring, \\ MD 20910-3281, USA
}

Correspondence should be addressed to Yanyun Liu; yanyun.liu@noaa.gov

Received 29 September 2013; Accepted 12 December 2013; Published 11 February 2014

Academic Editor: Lakshmi Kantha

Copyright (C) 2014 Yanyun Liu et al. This is an open access article distributed under the Creative Commons Attribution License, which permits unrestricted use, distribution, and reproduction in any medium, provided the original work is properly cited.

\begin{abstract}
Ocean circulation and water mass characteristics around the Galápagos Archipelago are studied using a four-level nested-domain ocean system (HYCOM). The model sensitivity to atmospheric forcing frequency and spatial resolution is examined. Results show, that with prescribed atmospheric forcing, HYCOM can generally simulate the major El Niño events especially the strong 19971998 events. Waters surrounding the archipelago show a large range of temperature and salinity in association with four different current systems. West zones of Isabella and Fernandina Islands are the largest upwelling zones, resulting from the collision of the Equatorial Undercurrent (EUC) with the islands, bringing relatively colder, salty waters to the surface and marking the location of the highest biological production. Model results, which agree well with observations, show a seasonal cycle in the transport of the EUC, reaching a maximum during the late spring/early summer and minimum in the late fall. The far northern region is characterized by warmer, fresher water with the greatest mixed layer depth as a result of Panama Current waters entering from the northeast. Water masses over the remainder of the region result from mixing of cool Peru Current waters and upwelled Cold Tongue waters entering from the east.
\end{abstract}

\section{Introduction}

The Galápagos Archipelago (Figure 1) lies in the equatorial eastern Pacific Ocean, about $1000 \mathrm{~km}$ west from the coast of Ecuador, South America. It can reasonably claim to possess the most distinctive marine flora and fauna and unique species for any area of its size worldwide [1]. Thus in March 1998, Ecuador created the Galápagos Marine Reserve (GMR), which is an extensive area, over $140,000 \mathrm{~km}^{2}$ and it consists of an extremely variable ecological system in space and time [2]. The main reason why the GMR features such great diversity lies in its positioning in a complex transition zone between tropical and subtropical waters and intense local upwelling zones. Because of this strong temporal and spatial variability, it would be extremely difficult to monitor or explain the sources of the ecological variability using an observing system alone. The work described here results from a combined field remotely sensed and modeling effort to study the connectivity of the upwelling dynamics over the GMR. During 2006-2007, a series of 5 archipelago-wide shipborne surveys, supported by moorings in 5 of the major upwelling regions together with remotely sensed observation and development of a high-resolution hydrodynamical model of the GMR, were carried out by a joint program of the University of North Carolina Wilmington, North Carolina State University, Mote Marine Laboratory, Charles Darwin 


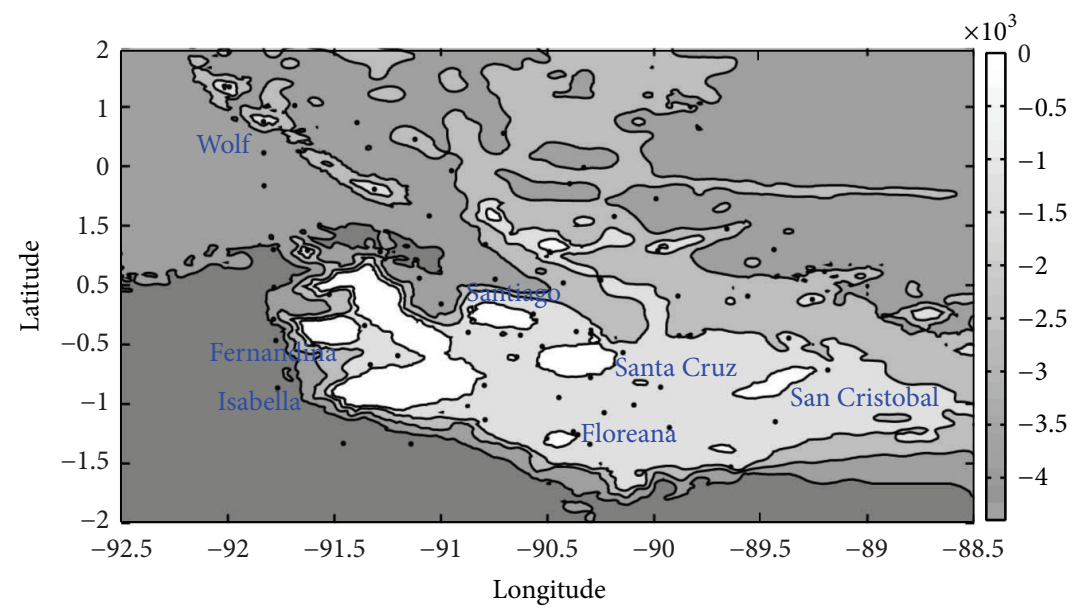

FIGURE 1: Bathymetry map and sampling stations of the Galápagos Archipelago.

Research Station, and the Galápagos Nation Park Service which was supported by NASA's Biodiversity and Ecological Monitoring and Biological Oceanography Programs. The first results of the model development and testing are described in this paper, with the observed ocean spatial and time series data used to validate the modeling effort. As might be expected, the biological response to physical forcing within the Galápagos Marine Reserve is the ultimate goal of this activity.

The Galápagos Archipelago ecosystem is mainly affected by waters from three different surface and subsurface currents. The major currents affecting the Galápagos are the westward South Equatorial Current (SEC) and the eastward Equatorial Undercurrent (EUC) [3-5]. The SEC drives surface waters over the entire region around the Galápagos and is affected by warmer northern hemisphere waters and by the Panama Current and cool Humboldt Current generated in the Peru upwelling zone, as well as cool southern hemisphere waters. The warm Panama Current influences primarily the northern islands, while the cool Humboldt (Peru) Current influences primary the southern and central portions of the archipelago. To balance the westward SEC as it flows to the west along the equator, the eastward EUC (also known as the Cromwell Current) [6] develops as a subsurface (subthermocline) compensation against the westward SEC. The collision of the subsurface EUC with the Galápagos platform results in topographically induced upwelling in western archipelago (particularly along Isabella Island). This upwelled water is relatively rich in iron, the macronutrient needed for growth by most organisms, and the production is high in many areas of the Galápagos and surrounding waters [7].

The Galápagos are greatly affected by seasonal atmospheric and oceanographic variability [8]. During the hot wet season (December to May), the Intertropical Convergence Zone (ITCZ) migrates southward towards the equator, the northeast trades become more prevalent, and warmer $\left(>25^{\circ} \mathrm{C}\right)$, fresher $(<34)$, and less-productive waters of the Panama Current flow southward into the archipelago. During the dry Garúa season (May to November), the ITCZ migrates to the north of the equator, the southeast trade winds become dominant, and the major source waters for the SEC are the cold Peruvian Ocean current and the Peruvian Coastal Current (the Humboldt Current), enhancing the contributions to the SEC with the colder $\left(18^{\circ} \mathrm{C}-20^{\circ} \mathrm{C}\right)$, saltier $(>35)$ productive waters. The different source waters for the SEC as it flows though the GMR, from both northern and southern hemispheres, as well as topographically induced upwelling which occurs when the eastward flowing EUC runs into the Galápagos platform are the cause of the tremendous diversity around the archipelago.

A few studies have quantified the primary production around the archipelago, especially higher concentrations in west of Isabella $[9,10]$ from the upwelling EUC. Houvenaghel [8] discussed the oceanographic setting of the Galápagos and concluded that the EUC was the major oceanographic phenomena affecting the Galápagos. Hayes [11] pointed out that the sea level differences across the Archipelago increase as the EUC strengthens, measured by shallow moored pressure gauges. Steger et al. [7] found that the near-surface waters to the west of the Archipelago during November 1993 were predominately upwelled EUC waters, and as a consequence were cooler, saltier and higher in nutrients and iron than waters found over the eastern portion of the Archipelago. In addition, the extent of the plume shown by Feldman [10] could only be maintained by upwelling of EUC waters that are cooler and higher in nutrients than the waters surrounding the plume. Palacios [12] also found that the temporal variability of ocean color and SST around the Galápagos was dominated by the seasonal migration of the ITCZ and associated strengthening of the SEC and EUC.

Another distinctive feature associated with Galápagos coastal waters that the greatest sea temperature anomalies occur during El Niño and La Niña events [13]. Recently, the frequency and severity of El Niño events appear to have increased and this is a concern for the conservation of endangered species. El Niño events now occur 2-7 times more frequently than they did 7000-15,000 years ago [14, 15]. The 1982-83 and 1997-98 El Niño events, in particular, 
appear to have been the most extreme for many centuries, and have had a devastating effect on marine life in the Galápagos region. During the El Niño event period, the Equatorial Undercurrent weakens, the upwelling weakens or stops altogether, the surface water warms, macronutrients are reduced, the primary production decreases and fish numbers diminish $[10,16]$. So the relationship between extreme ENSO events and loss of marine biodiversity in Galápagos needs to be investigated as a matter of local and global importance. Such a study has direct implications to predictions of loss of global biodiversity associated with ocean warming and climate change.

Previous modeling studies by Brentnall [17] and Eden and Timmerman [18] firstly described the response of currents and sea surface temperature (SST) to the presence of the Galápagos. Eden and Timmerman [18] found changes in the regional pattern of SST of west of the Galápagos due to island-induced changes in TIW activity to be as important as those resulting from direct interaction with the mean flow (e.g., partially deflecting the EUC). Cravatte et al. [19] studied the seasonal, interannual, and decadal variability in eastern Pacific Ocean using $2^{\circ}$ ocean general circulation model (OGCM) and described that adding the Galapagos Archipelago to the model bathymetry only induces very local changes in the equatorial Pacific. The OGCM studies by Karnauskas et al. [5] described the effect of the Galápagos Islands on the equatorial Pacific Cold Tongue using the $0.25^{\circ}$ ocean model. As suggested by Karnauskas et al. [20], the EUC in the eastern Pacific Ocean can be underestimated due to insufficient ocean resolution. This paper focuses on the oceanographic variability at different spatial scales associated with the biological productivity and biogeography of the various marine ecosystems across the GMR as simulated by a high-resolution ocean general circulation model, specifically, the Hybrid Coordinate Ocean Model (HYCOM) [21-23]. For the first time, the ocean model is downscaled from the global ocean to the GMR region using the multiscale ocean circulation model system. The rest of the paper is organized as follows: in Section 2, we describe the HYCOM model configuration and do some sensitivity experiments. In Section 3, the simulated tropical ocean circulation around the GMR using QuikSCAT and NCEP forcing is demonstrated and compared with the observation cruise results. Results are discussed in Section 4 and summarized in Section 5.

\section{HYCOM Model and Data}

2.1. Model Description. HYCOM is a primitive equation ocean general circulation model using density, pressure, and sigma coordinates in the vertical coordinate. It has evolved from the Miami Isopycnic Coordinate Ocean Model (MICOM) and is isopycnal in the open stratified ocean but reverts to a terrain-following coordinate in shallow coastal regions, and to $z$-level coordinates near the surface in the mixed layer. This generalized vertical coordinate approach is dynamic in space and time via the layered continuity equation and permits the existence of zero thickness layers. HYCOM's ability to seamless transition between deep and

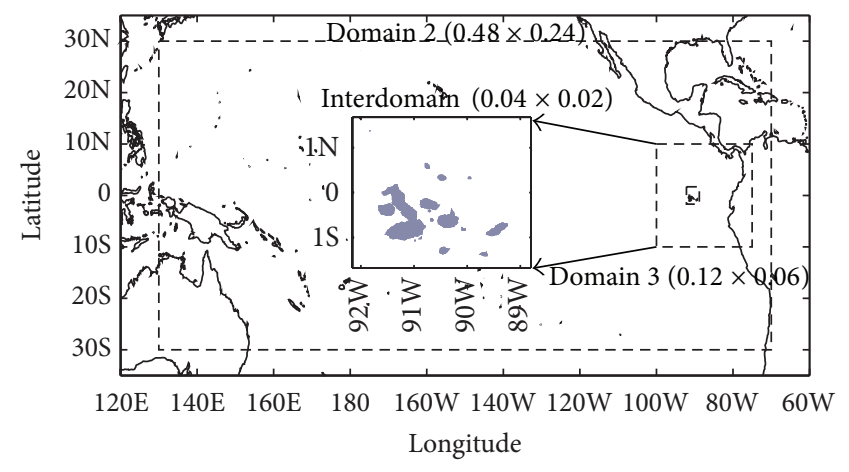

FIgUre 2: Model domain size: the outer domain is global ocean (not shown here, with the resolution of $1.44^{\circ} \times 0.72^{\circ}$ ), and the intermediate domains (covering the eastern Pacific Ocean, with the resolution of $0.48^{\circ} \times 0.24^{\circ}$ and $\left.0.12^{\circ} \times 0.06^{\circ}\right)$, and the interdomain with the highest resolution of $0.04^{\circ} \times 0.02^{\circ}$.

shallow water yield of more reliable ocean circulation makes it ideal to apply to the GMR. The islands lie in the Pacific Ocean about $1,000 \mathrm{~km}$ from the south American coast and are straddling the equator. There are 13 large islands, 6 smaller ones, and 107 islets and rocks, with a total land area of about 8,000 square kilometers, together with uncounted seamounts (Stuart Banks, personnel communication). The islands are volcanic in origin and several volcanoes in the west of the archipelago are still very active. These volcanoes rise from a depth of $>3500 \mathrm{~m}$ with the main platform at $\sim 500 \mathrm{~m}$ depth. As shown by Chassignet et al. [22], HYCOM was able to generate a more realistic EUC than several other popular OGCMs [22]. Since understanding the dynamics of the EUC is crucial to this study, HYCOM is an appropriate choice for simulating the ocean circulation around the GMR [24].

The details of the HYCOM equations and numerical algorithms, along with a description and validation of the hybrid coordinate generator, can be found in Bleck [21].

\subsection{Model Configuration and Numerical Experiments. A} suite of HYCOM simulations was carried out using a nesting scheme of 4 ever increasing resolution domains (see Figure 2). The largest domain covers the entire global ocean with a grid size of $1.44^{\circ} \times 0.72^{\circ}$ in the zonal and meridional directions, respectively. The second domain embedded within the global domain uses a grid size of $0.48^{\circ} \times 0.24^{\circ}$ covering the equatorial Pacific Ocean. The third domain has a grid size of $0.12^{\circ} \times 0.06^{\circ}$. Finally, the highest resolution domain has a grid size of $0.04^{\circ} \times 0.02^{\circ}$ (about $4.45 \mathrm{~km} \times$ $2.21 \mathrm{~km})$ that is centered on the GMR $\left(92.16^{\circ} \mathrm{W}-88.96^{\circ} \mathrm{W}\right.$, $\left.1.68^{\circ} \mathrm{S}-1.68^{\circ} \mathrm{N}\right)$. All domains have a vertical resolution of 26 layers that stretch or shrink vertically as a function of total depth according to the hybrid coordinate frame discussed above.

The model was initialized with temperature and salinity from the Levitus monthly climatology $[25,26]$ and run for 12 years. It was driven by daily surface wind stress, surface air temperature, surface atmospheric specific humidity, net shortwave radiation, net long-wave radiation, and 


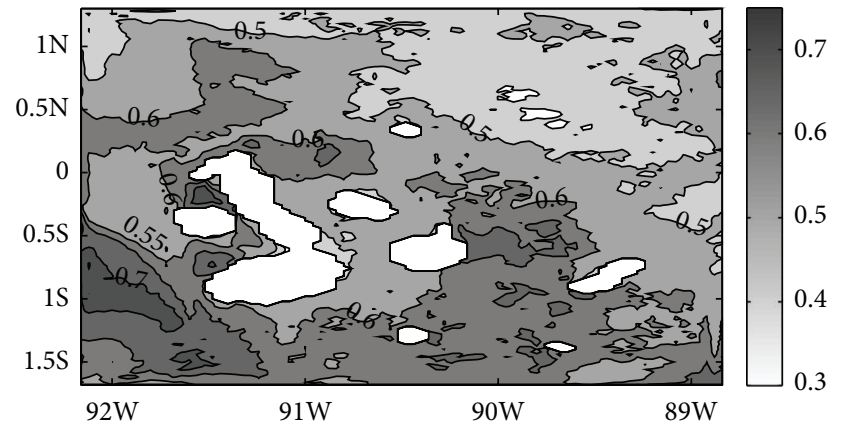

(a) Reso $=0.04$

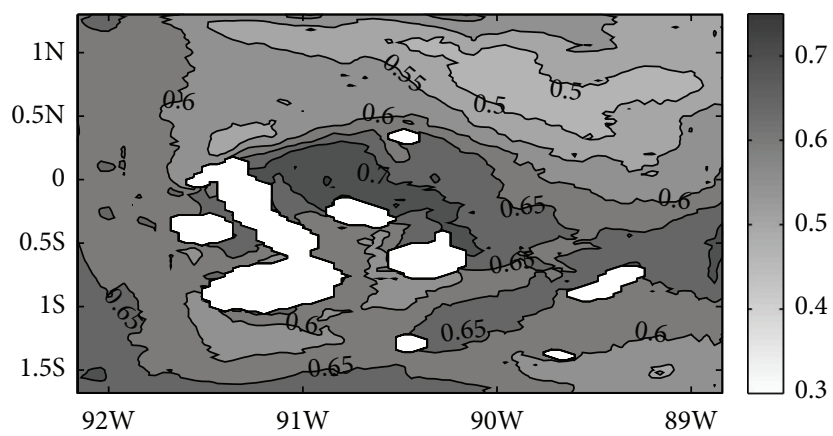

(c) Reso $=0.48$

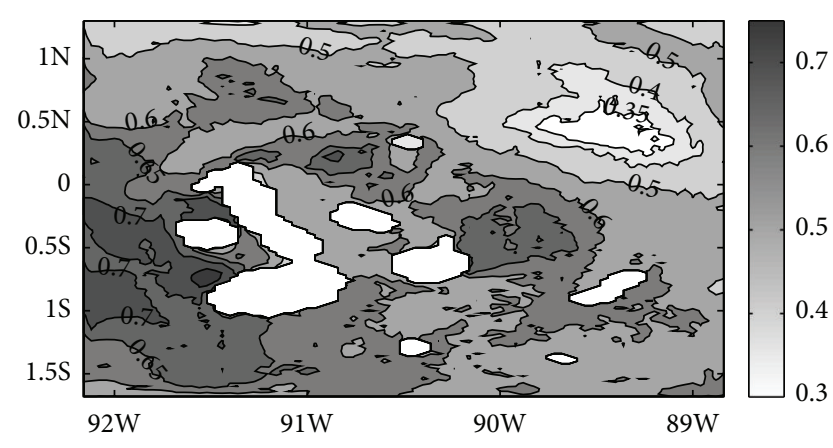

(b) Reso $=0.12$

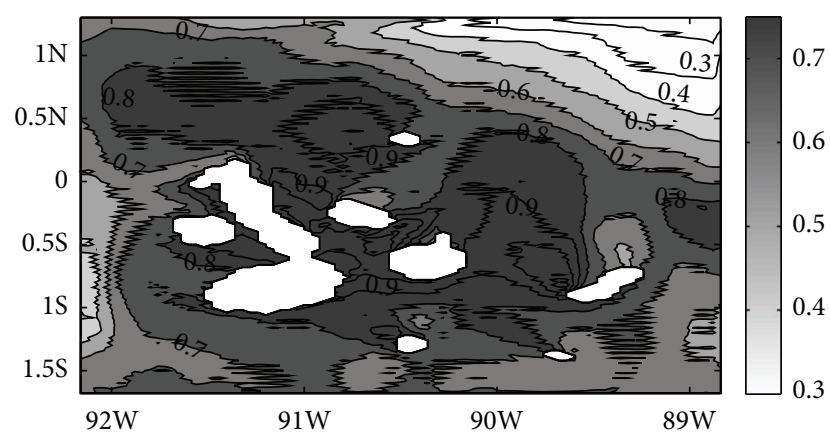

(d) Reso $=1.44$

FIGURE 3: Simulations with different winds forcing, from the 6-hourly wind (a), daily mean wind (b), weekly mean wind (c), to the monthly wind forcing $(\mathrm{d})$.

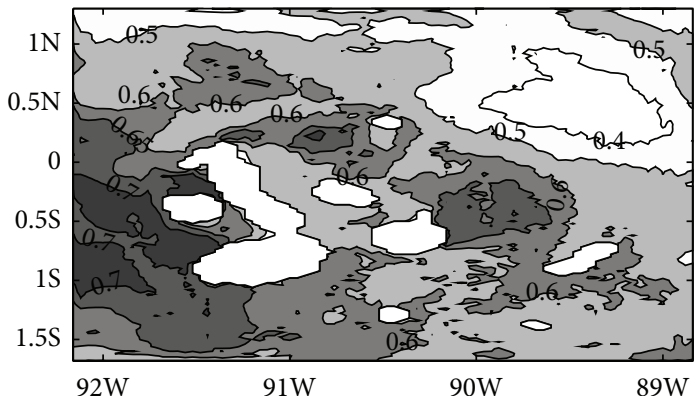

(a) Reso $=0.04$

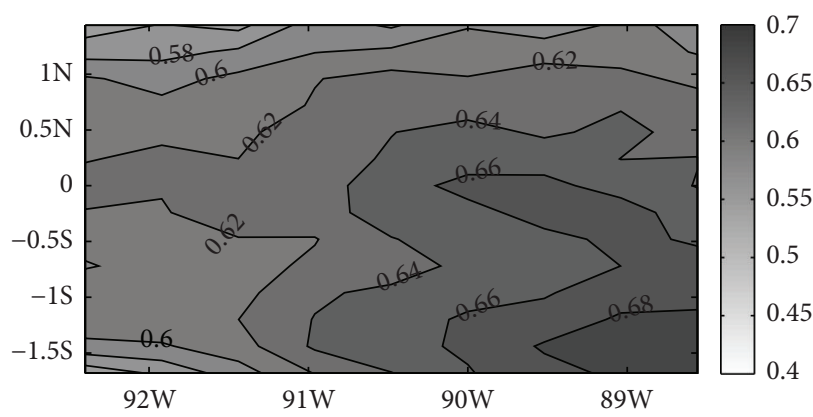

(c) Reso $=0.48$

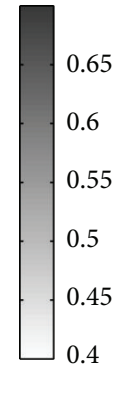

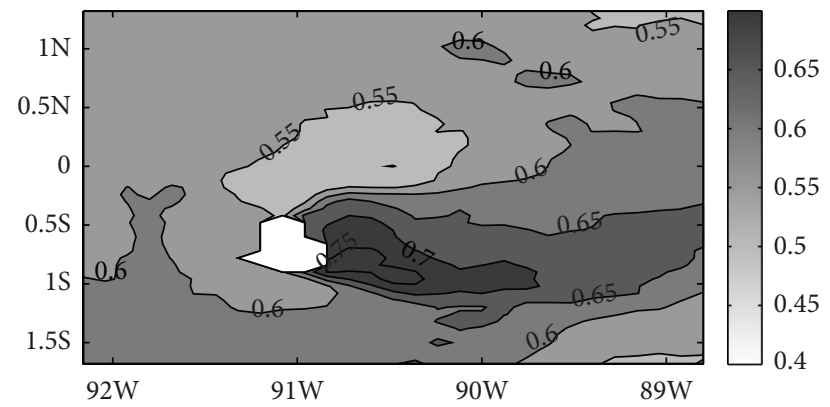

(b) Reso $=0.12$

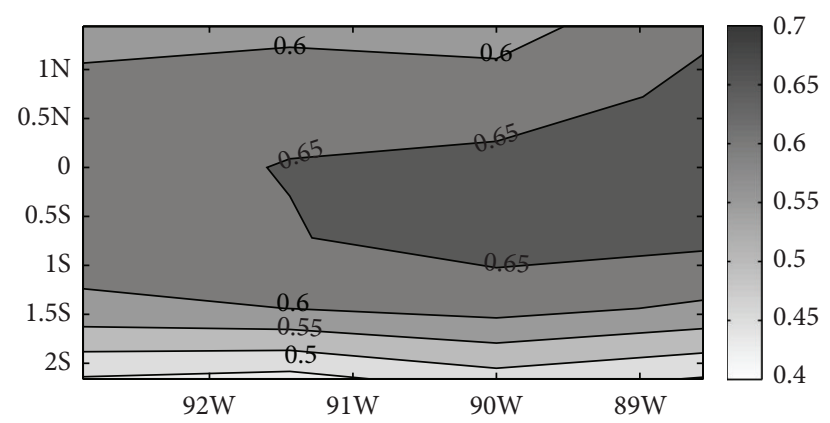

(d) Reso $=1.44$

Figure 4: Simulations with different horizontal resolutions $\left(0.04^{\circ}, 0.12^{\circ}, 0.48^{\circ}\right.$, and $\left.1.44^{\circ}\right)$. 


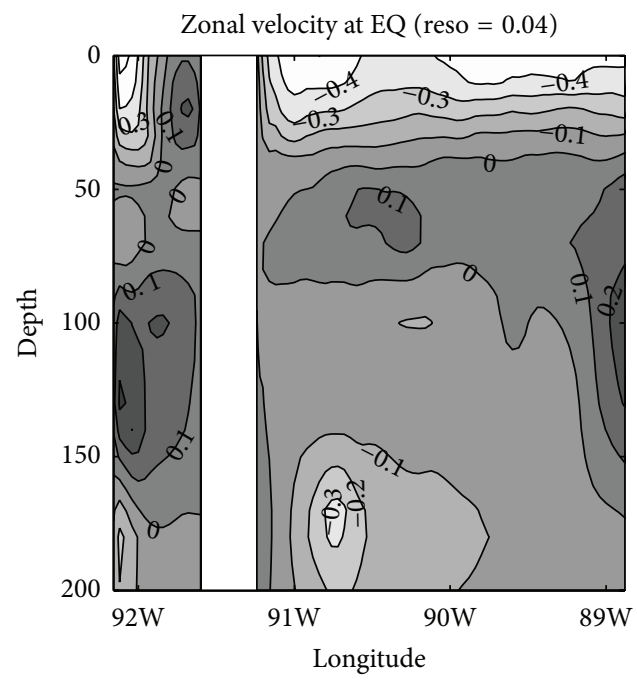

(a)

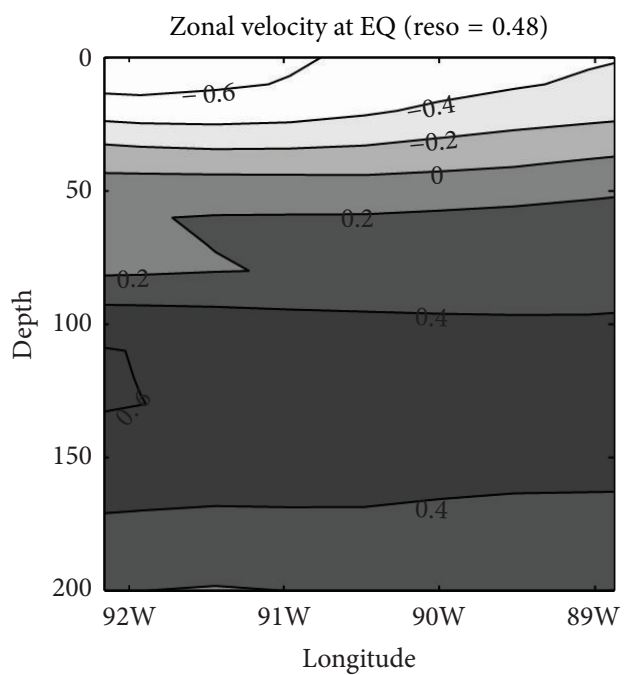

(c)

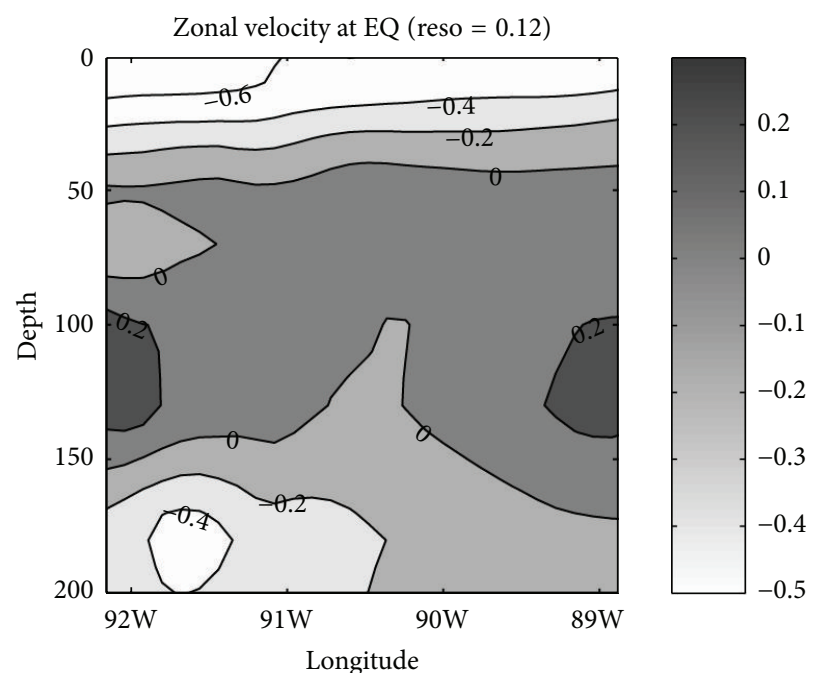

(b)

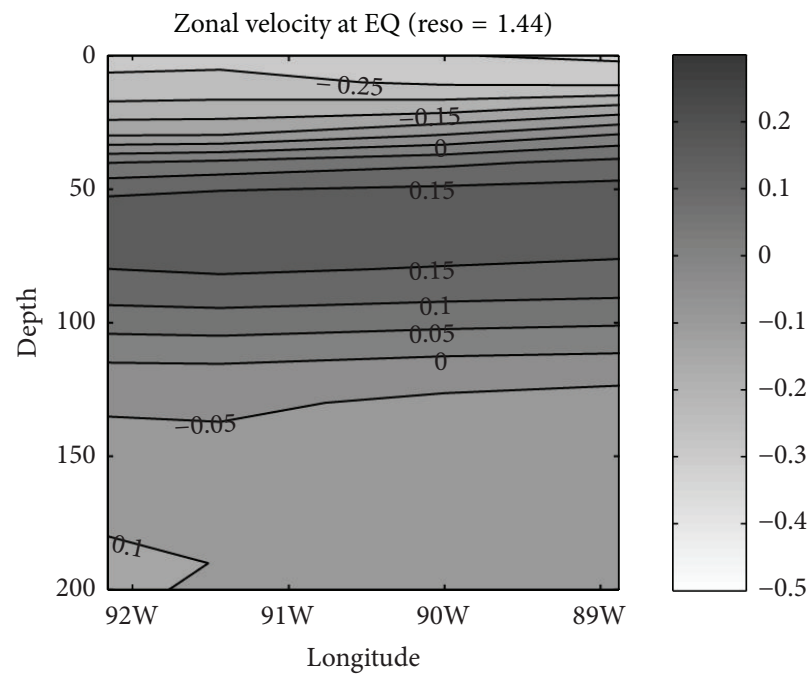

(d)

FIGURE 5: Vertical sections of zonal current (m/s) along the equator for the upper $200 \mathrm{~m}$ around the GMR with different horizontal resolutions (a) $0.04^{\circ}$, (b) $0.12^{\circ}$, (c) $0.48^{\circ}$, and (d) $1.44^{\circ}$.

precipitation fields obtained from NCEP reanalysis [27]. The latent and sensible heat fluxes were calculated during model runs using the model sea surface temperature and the bulk formulation $[28,29]$. Boundary conditions were provided by buffer zones that are ten grid points wide within which temperature, salinity, and interface depth are relaxed to Levitus climatological values that have been vertically remapped to hybrid vertical coordinates. The KPP vertical mixing model of Large et al. [30] was used, which has been shown to perform well in open ocean settings. For the experiments with the resolution of $1.44^{\circ}, 0.48^{\circ}$, and $0.12^{\circ}$, the bathymetry was derived from ETOPO2, which is a digital data base of seafloor and land elevations on a 2-minute latitude/longitude grid and is interpolated onto the various model grids. The bathymetry for the simulation of the resolution of $0.04^{\circ}$ (near the Galápagos Islands) domain is derived from the $0.01^{\circ}$ bathymetry of William Chadwick at Oregon State
University (http://www.pmel.noaa.gov/vents/staff/chadwick/ galapagos.html). The wind field used to drive the ocean circulation in this subregion was derived from the $25 \mathrm{~km}$ resolution QuikSCAT wind field instead of the NCEP/NCAR reanalysis from year 2000 to year 2006. The model was run for twelve years from 1995 to 2006, and fields from the last two years of the simulation (years 2005 and 2006) are analyzed here.

2.3. Sensitivity Experiments. Two types of sensitivity experiments were conducted to test the ocean variability around the GMR. One experiment was to test how marine mesoscale variability depends on temporal and spatial scales of the wind forcing (Expt.1); the other is to test how marine variability depends on different model horizontal resolutions (Expt.2). The ENSO variability was also simulated using the model to 
quantify the ability of the model to give realistic simulations of ENSO events around the islands.

2.3.1. Wind Forcing Experiments. In the wind forcing experiments (Expt.1), the HYCOM model was run with four different winds forcing: monthly mean forcing, weekly mean forcing, daily mean forcing, and 6-hourly wind forcing. The high frequency daily mean forcing and 6-hourly wind forcing were downloaded from http://www.cdc.noaa.gov/cdc/reanalysis/, while the monthly mean forcing and weekly mean forcing were computed by using the daily mean forcing data. Figure 3 shows the standard deviation of sea surface temperature (SST) with the four different wind forcing. From this figure, the simulation with the monthly wind forcing has the largest standard deviation $\left(0.7^{\circ} \mathrm{C}\right)$ over most of the GMR, while the standard deviations from the simulations with the high frequency wind forcing are similar but much smaller than those with the low frequency forcing. The result shows that monthly wind forcing is not adequate to resolve the ocean variability around the archipelago; therefore, especially in our region of interest, it is essential to use high frequency wind forcing.

2.3.2. Model Resolution Experiments. In the horizontal resolution experiments (Expt.2), the model was run centered on the GMR $\left(92.16^{\circ} \mathrm{W}-88.96^{\circ} \mathrm{W}, 1.68^{\circ} \mathrm{S}-1.68^{\circ} \mathrm{N}\right)$ with four different horizontal resolutions $-0.04^{\circ}\left(0.04^{\circ} \times 0.02^{\circ}\right), 0.12^{\circ}$ $\left(0.12^{\circ} \times 0.06^{\circ}\right), 0.48^{\circ}\left(0.48^{\circ} \times 0.24^{\circ}\right)$, and $1.44^{\circ}\left(1.44^{\circ} \times 0.72^{\circ}\right)$. Figure 4 displays the SST standard deviation at these different resolutions. As shown by Figure 4, the simulations around the GMR show that a $0.04^{\circ}$ resolution is more suitable to study the variability in and around the Galápagos.

In the equatorial Pacific Ocean, the zonal transport is mainly dominated by the eastward EUC and the westward SEC. The changes to the EUC are also found with different resolutions (Figure 5). Figure 5 presented the vertical sections of zonal current along the equator for the upper $200 \mathrm{~m}$ around the GMR with different horizontal resolutions. The core of the EUC is located at $50-100 \mathrm{~m}$. With increasing model resolution, the EUC speed is decreased and elevated to the surface with the inclusion of the Galápagos Islands under the fine $0.04^{\circ}$ resolution. Figure 6 shows the region-averaged (within the whole GMR domain) SST simulated using four different horizontal resolutions $\left(0.04^{\circ}, 0.12^{\circ}, 0.48^{\circ}\right.$, and $\left.1.44^{\circ}\right)$ and the regionaveraged observed SST. The observational datasets used for comparison with model output came from the $0.25^{\circ} \times 0.25^{\circ}$ microwave $(\mathrm{MW})+$ infrared (IR) optimally interpolated (OI) microwave SST product from 2002 to present (http://www.remss.com/sst/microwave_oi_sst_browse.html).

These figures show that the simulated SST with a resolution of $0.04^{\circ}$ is the closest to the observed SST. The correlation coefficient between the two reaches $0.72(P<$ $0.05)$, while the correlation coefficients between the simulated and observed SST using the different resolutions of $0.12^{\circ}$, $0.48^{\circ}$, and $1.44^{\circ}$ are $0.67,0.61$, and 0.32 , respectively. Figure 7 depicts the region-averaged (see Figure 7(e): four different regions in eastern Pacific-region 1: $97.2^{\circ} \mathrm{W}-92.88^{\circ} \mathrm{W}$,

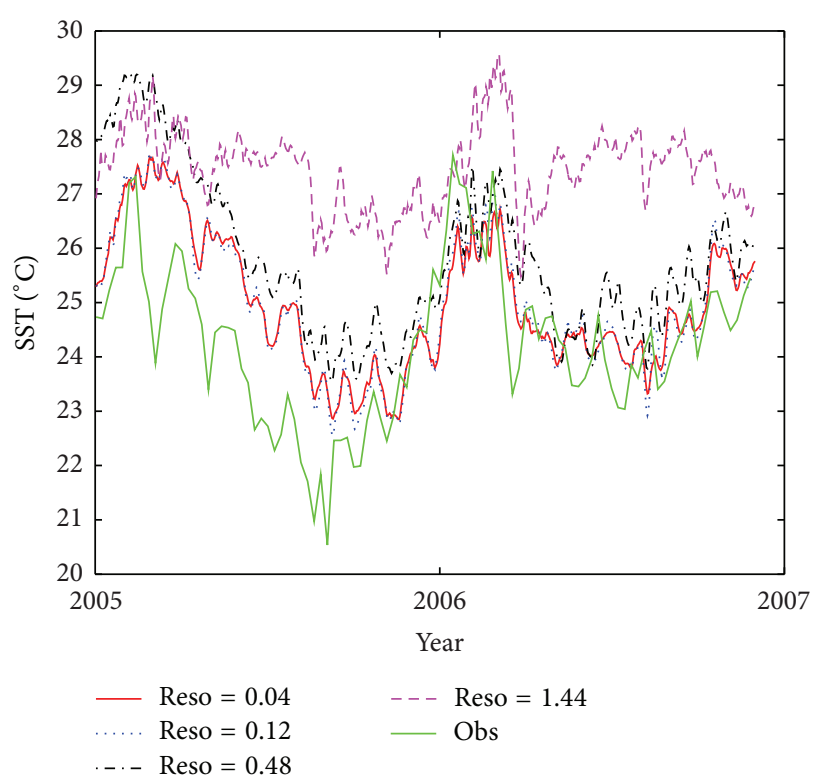

FIGURE 6: The region-averaged around GMR $\left(92.16^{\circ} \mathrm{W}-88.96^{\circ} \mathrm{W}\right.$, $\left.1.68^{\circ} \mathrm{S}-1.68^{\circ} \mathrm{N}\right)$ simulated SST under four different horizontal resolutions $\left(0.04^{\circ}, 0.12^{\circ}, 0.48^{\circ}\right.$, and $\left.1.44^{\circ}\right)$ and the region-averaged observed SST.

TABLE 1: Correlation coefficients between the observed and simulated SST using the different resolution of $0.12^{\circ}, 0.48^{\circ}$, and $1.44^{\circ}$ in the four different regions (shown in Figure 7).

\begin{tabular}{lcccc}
\hline Resolution & Region 1 & Region 2 & Region 3 & Region 4 \\
\hline $0.12^{\circ}$ & 0.69 & 0.59 & 0.55 & 0.89 \\
$0.48^{\circ}$ & 0.67 & 0.53 & 0.48 & 0.83 \\
$1.44^{\circ}$ & 0.56 & 0.46 & 0.36 & 0.72 \\
\hline
\end{tabular}

$2.16^{\circ} \mathrm{S}-2.16^{\circ} \mathrm{N}$; region $2: 90^{\circ} \mathrm{W}-85.68^{\circ} \mathrm{W}, 2.16^{\circ} \mathrm{S}-2.16^{\circ} \mathrm{N}$; region 3: $90^{\circ} \mathrm{W}-85.68^{\circ} \mathrm{W}, 6.5^{\circ} \mathrm{S}-2.16^{\circ} \mathrm{S}$; region $4: 90^{\circ} \mathrm{W}-85.68^{\circ} \mathrm{W}$, $2.16^{\circ} \mathrm{N}-6.5^{\circ} \mathrm{N}$ ) simulated SST using three different horizontal resolutions $\left(0.12^{\circ}, 0.48^{\circ}\right.$, and $\left.1.44^{\circ}\right)$ and the corresponding region-averaged observed SST. Table 1 shows the correlation coefficients between the observed and simulated SST. The result shows that the simulation using higher resolution has the higher correlation with observed data. All above results show that the simulated SST using higher resolution (i.e., $0.04^{\circ}$ resolution) is more suitable to study the variability in and around the Galápagos.

2.3.3. ENSO Simulations. As a final test of the configurations to be used in this study, El Niño/Southern Oscillation (ENSO) variability was simulated using HYCOM driven by NCEP wind forcing. The SST anomalies in the Nino3.4 region $\left(5^{\circ} \mathrm{S}-\right.$ $5^{\circ} \mathrm{N}, 150^{\circ} \mathrm{W}-90^{\circ} \mathrm{W}$ ) are often used to index ENSO variability [31]. Figure 8 shows the observed (blue) and HYCOM simulated SST anomalies (red) in Nino3.4 region. The correlation coefficient between the simulate SSTA and observed SSTA is 0.883 . This result shows that, with prescribe atmospheric surface forcing, HYCOM can generally simulate the major El Niño events especially the strong 1997-1998 events. Therefore, 


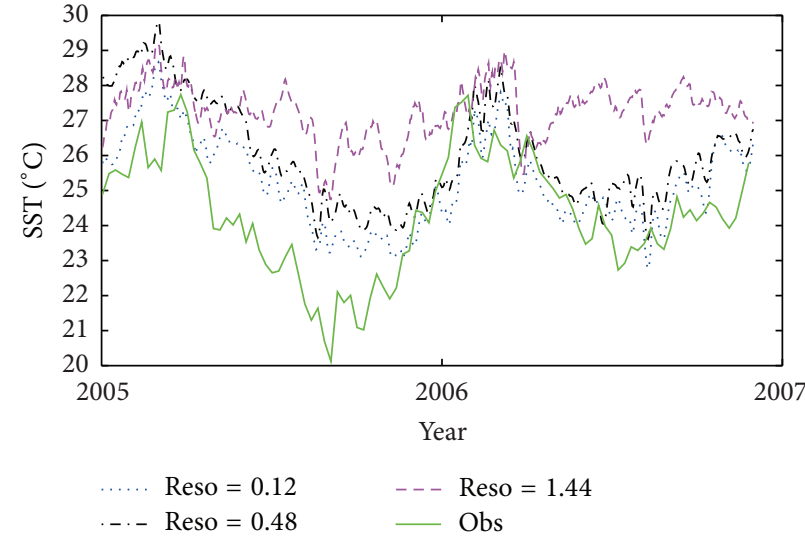

(a) SST in region 1

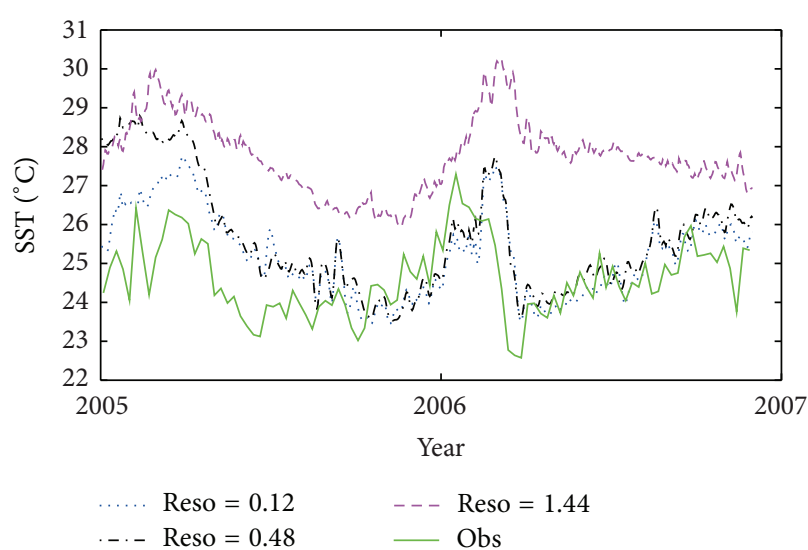

(c) SST in region 3

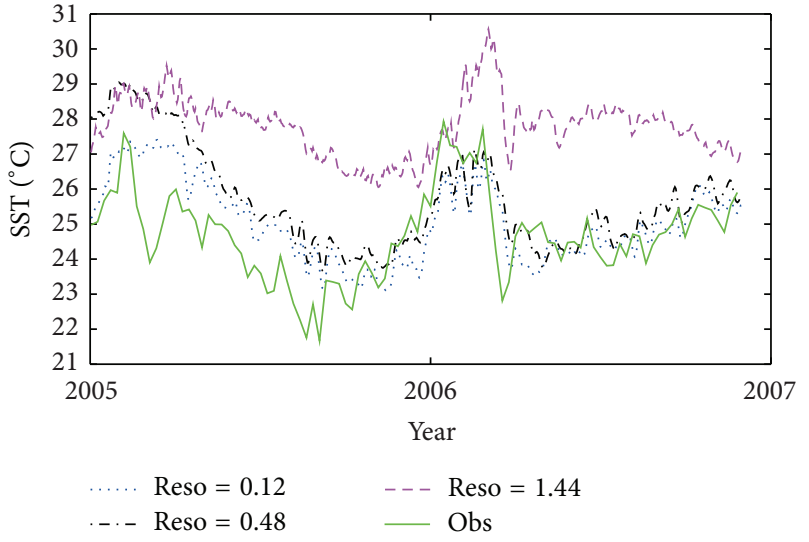

(b) SST in region 2

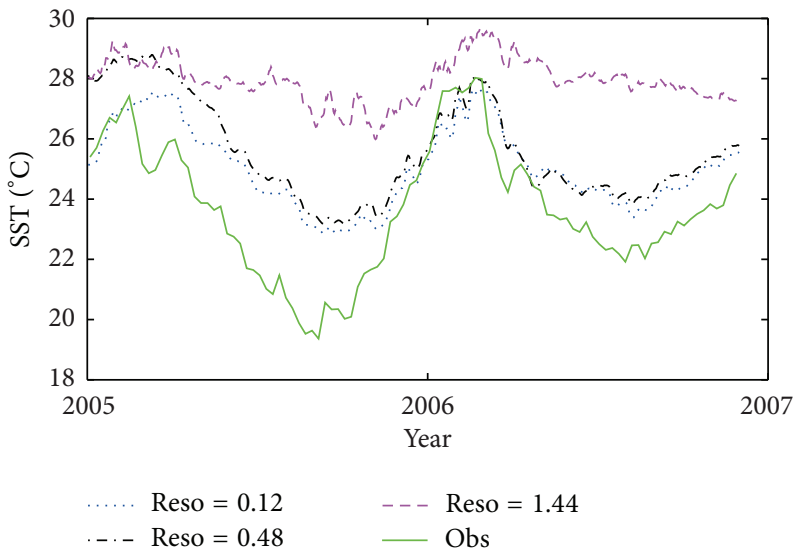

(d) SST in region 4

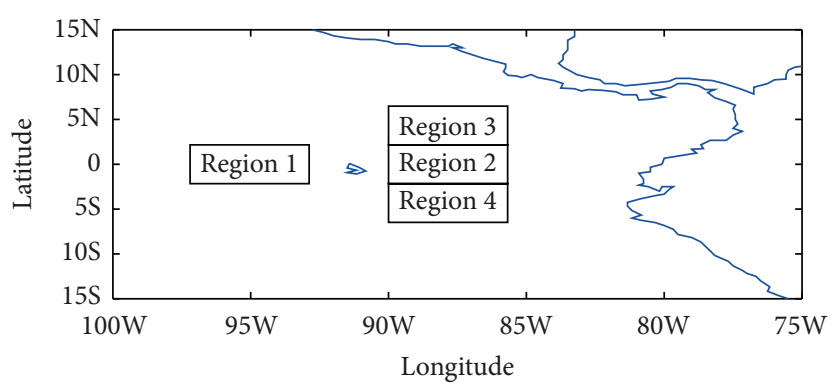

(e) Region map

Figure 7: The region-averaged (four different regions in eastern Pacific, see Figure 7(e), region 1: $97.2^{\circ} \mathrm{W}-92.88^{\circ} \mathrm{W}, 2.16^{\circ} \mathrm{S}-2.16^{\circ} \mathrm{N}$; region 2 : $90^{\circ} \mathrm{W}-85.68^{\circ} \mathrm{W}, 2.16^{\circ} \mathrm{S}-2.16^{\circ} \mathrm{N}$; region $3: 90^{\circ} \mathrm{W}-85.68^{\circ} \mathrm{W}, 6.5^{\circ} \mathrm{S}-2.16^{\circ} \mathrm{S}$; region $4: 90^{\circ} \mathrm{W}-85.68^{\circ} \mathrm{W}, 2.16^{\circ} \mathrm{N}-6.5^{\circ} \mathrm{N}$ ) simulated SST under three different horizontal resolutions $\left(0.12^{\circ}, 0.48^{\circ}\right.$, and $\left.1.44^{\circ}\right)$ and the region-averaged observed SST.

we feel confident that the HYCOM should give realistic simulations of the large-scale circulation around the islands during ENSO events as well as normal years.

\section{Model Simulations Compared to Observations}

3.1. Simulation of T-S and Ocean Currents around GMR. Here we compare the simulated circulation around the GMR to observational cruise results, focusing on the surface water mass characteristics and flow patterns. It should be noted that it is not expected that the modeled fields (which represent greater than 10,000 grid points over the water regions of the GMR) accurately portray the observed fields (which represent gridded data from approximately 60-70 data points depending on the cruise) but should portray the major features of the water masses and currents (from our validation experiments using SST, the model data may actually portray the features better than the observed data). 
The observation data used in the study were collected during four surveys (see station positions in Figure 1) conducted from 17 to 28 March, 2005 (Mar 2005), from November 22 to December 3, 2005, (Nov/Dec 2005), from June 26 to July 4, 2006 (Jun/Jul 2006), and from 14 to 23 November, 2006 (Nov 2006), onboard the Galápagos National Park Service's M/N Sierra Negra. Each cruise was 8 to 12 days long and occupied $\sim 70$ hydrographic stations around the GMR [32]. Surface data included underway measurements of temperature, salinity, dissolved oxygen, and fluorescence data using a Seabird Electronics SBE 19+ system (CTD) that was averaged into 30 min time intervals.

(a) March 2005. The March 2005 cruise occurred during the hot, wet season, a period characterized by warm SST associated with the southward advection of warmer, northern waters from the Panama Current and a weakening of the southeast trade winds. Figures 9(a) and 10(a) display the simulated and observed SST. Figures 11(a) and 12(a) display the simulated and observed sea surface salinity (SSS). Figure 13(a) display the simulated mixed layer depth (MLD) to compares with the observed chlorophyll (Figure 14(a)) during March 2005. From Figures 9(a) and 11(a), the warmest and the last salty waters are located within the north and south regions of the GMR and the coolest and the saltiest waters are found in the west of Isabella and Fernandina, indicative of topographically induced upwelling of the EUC [10]. These results are consistent with the observation cruise T-S characteristics (see Figures 10(a) and 12(a)). Also the MLD (Figure 13(a)) was the shallowest $(\sim 10 \mathrm{~m})$ in the west of Isabella and Fernandina during the March 2005 cruise. The coldest and the saltiest water had the highest chlorophyll concentration (see Figure 14(a)). The highest surface chlorophyll a concentrations observed of $3.25 \mathrm{mg} \mathrm{m}^{-3}$ were found in the west of Isabella Island and the north of Fernandina Island. The minimum chlorophyll $a$ concentration observed was $0.05 \mathrm{mg} \mathrm{m}^{-3}$ located directly in southeast of Isabella Island.

The simulated surface layer flow (Figure 15(a)) showed that the westward flow of the SEC collided with the eastward flow of the EUC in both north and south of Isabella Island. Near the Archipelago, the SEC splinters into northward and southward lobes that continue to the west with a few degrees off the equator [33]. The mixed layer flow (Figure 16(a)) is mainly dominated by the eastward flow of EUC around the Galápagos. The EUC is quite strong $(150 \mathrm{~cm} / \mathrm{s})$, has its core below the thermocline, and drives an eastward flow near surface $(\sim 20 \mathrm{~m})$. The mixed layer depth shoals to $15 \mathrm{~m}$ in the west of Isabella and Fernandina Islands, which indicates the upper reach of a weakened, centrally located EUC.

(b) November/December 2005. The November/December 2005 cruise occurred during a transition from the Garúa to the wet season with lessening of the southeast trades. The simulated mean SST was cooler than climatology by approximately $-0.5^{\circ} \mathrm{C}$ during the transition, as seen from the ENSO anomaly (Figure 8, grey area). Figures 9(b) and 10(b) display the simulated and observed SST. Figures 11(b) and 12(b) display the simulated and observed sea surface salinity (SSS). Figure 13(b) displays the simulated mixed layer

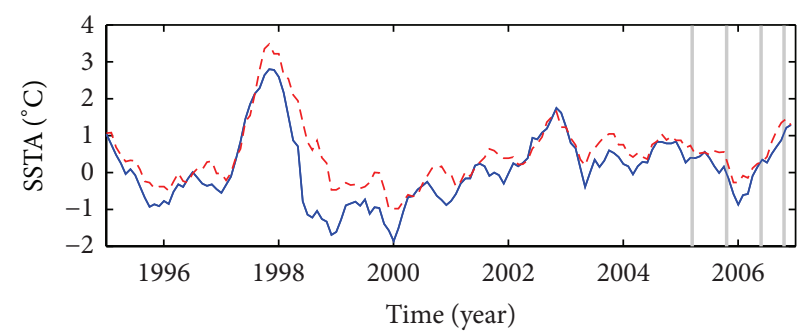

FIGURE 8: The observed (blue, dashed) and HYCOM simulated SST anomalies (red, solid) in Nino3.4 region. The grey shaded areas indicate the four cruise periods.

depth (MLD) to compare with the observed chlorophyll (Figure 14(a)) during November/December 2005. During this period, the modeled coldest $\left(20^{\circ} \mathrm{C}\right.$, see Figure 9 (b)) and saltiest (34.7, see Figure 11(b)) waters were found in the west of Isabella Island and north of Fernandina Island and corresponded with the largest upwelling zones found in late spring/early summer as the EUC strengthened. These features were consistent with the in situ T-S characteristics observed during this cruise period (see Figures 10(b) and 12(b)). Figure 13(b) shows that the MLD was slightly shallower in the west near the cooler, upwelling region. The warmest $\left(25.0^{\circ} \mathrm{C}\right)$ and the freshest (33.7) waters were found in north of the Archipelago. The far northern region was characterized with warmer, fresher water and had the deepest MLD, and the other regions fell between the range of upwelling region and far north region. Both the SST and SSS distributions showed an east-to-west gradient associated with higher values of chlorophyll concentrations indicative of higher phytoplankton biomass. The maximum values of chlorophyll $a$ were found in west of Isabella Island, and the minimum chlorophyll $a$ concentrations were observed along the equator in the GMR (Figure 14(b)). Also, the shallowest MLD was simulated over cooler waters at depth (Figures 13(b) and 9(b)), another indication of strong upwelling. The modeled surface layer flow (Figure 15(b)) was completely dominated by the westward flow of the SEC throughout the GMR during this period. The EUC (Figure 16(b)) had weakened considerably.

(c) June 2006. The June/July 2006 cruise occurred during a transition period, leaving the wet season and entering the Garúa season, with the strengthening of southeast trade winds and SST significantly $\left(+1.2^{\circ} \mathrm{C}\right)$ above climatology (Figure 8). Figures 9(c) and 10(c) display the simulated and observed SST. Figures 11(c) and 12(c) display the simulated and observed sea surface salinity (SSS). Figure 13(c) displays the simulated mixed layer depth (MLD) to compare with the observed chlorophyll (Figure 14(c)) during June 2006. The model mean temperature was $24.4 \pm 1.7^{\circ} \mathrm{C}$ throughout the GMR (Figure 9(c)) with the warmest waters, $26.0^{\circ} \mathrm{C}$, found in north of the archipelago and the coldest waters, $24.2^{\circ} \mathrm{C}$, found in the west of Isabella and Fernandina Islands (Figure 9(c)). The simulated SST was the warmest $\left(26.0^{\circ} \mathrm{C}\right.$ ) and SSS was the freshest in northeast of the Archipelago, forming an increasing gradient to the west with the highest 


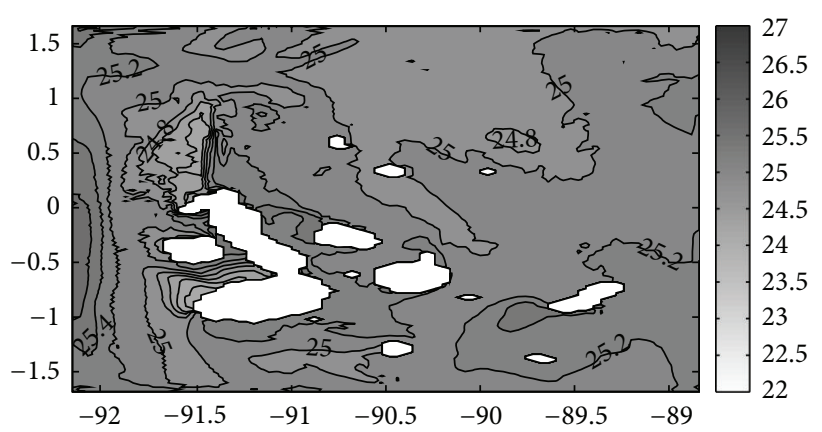

(a) Mar 2005

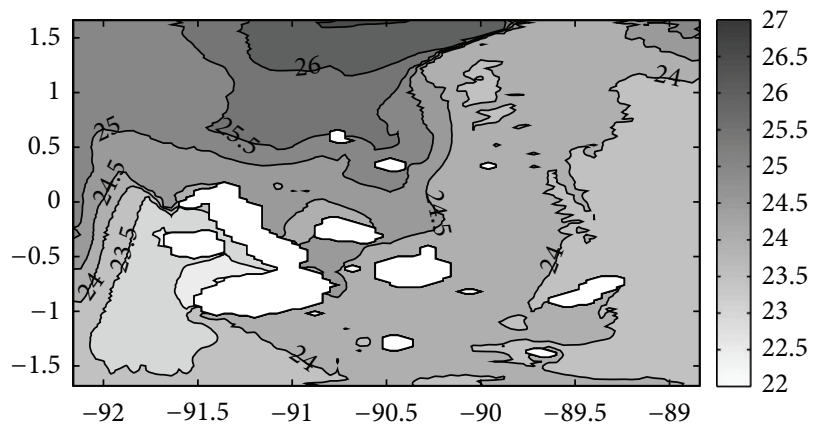

(c) Jun/Jul 2006

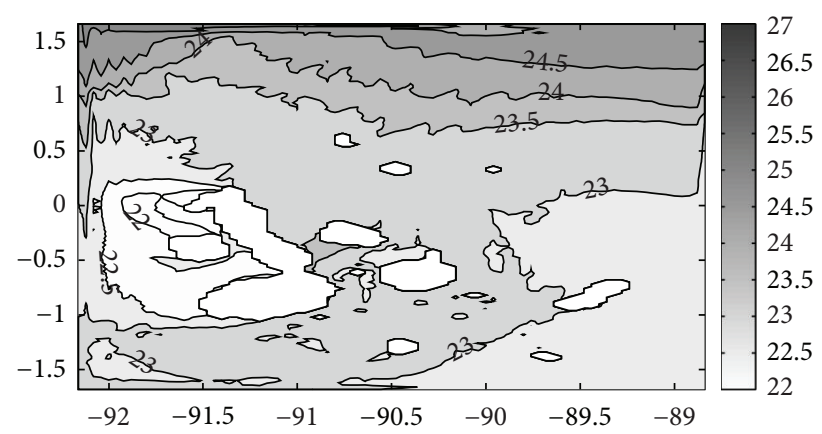

(b) Nov/Dec 2005

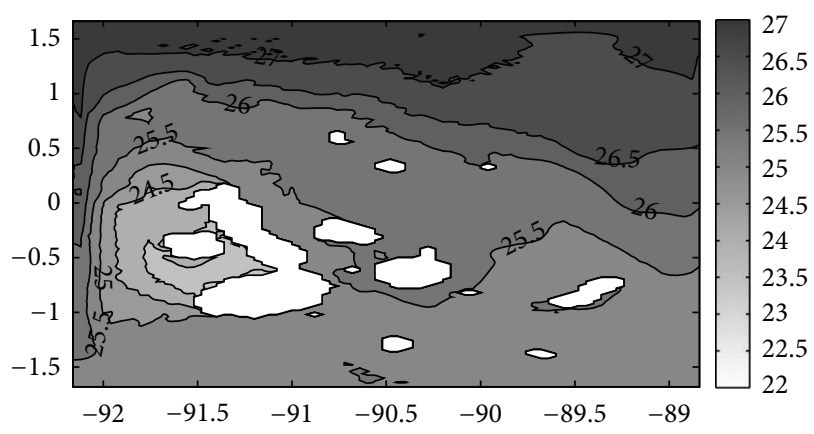

(d) Nov 2006

Figure 9: HYCOM simulated sea surface temperature for (a) March 2005, (b) November/December 2005, (c) June/July 2006, and (d) November 2006.

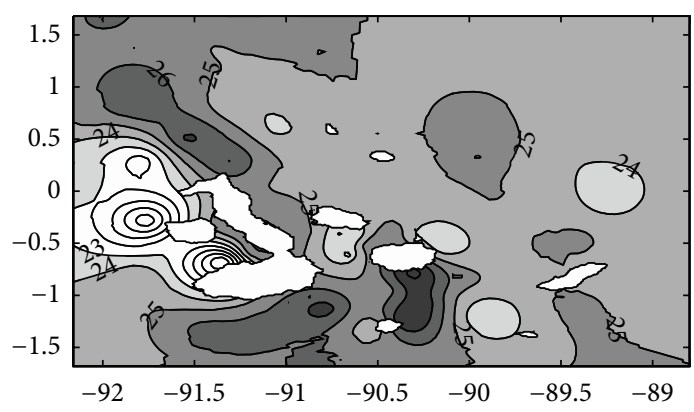

(a) Mar 2005

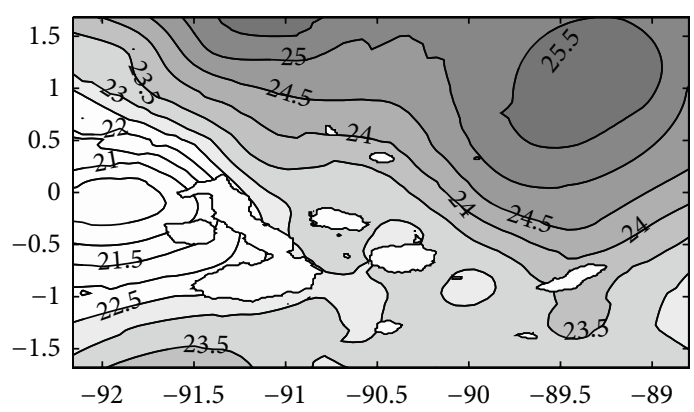

(c) Jun/Jul 2006
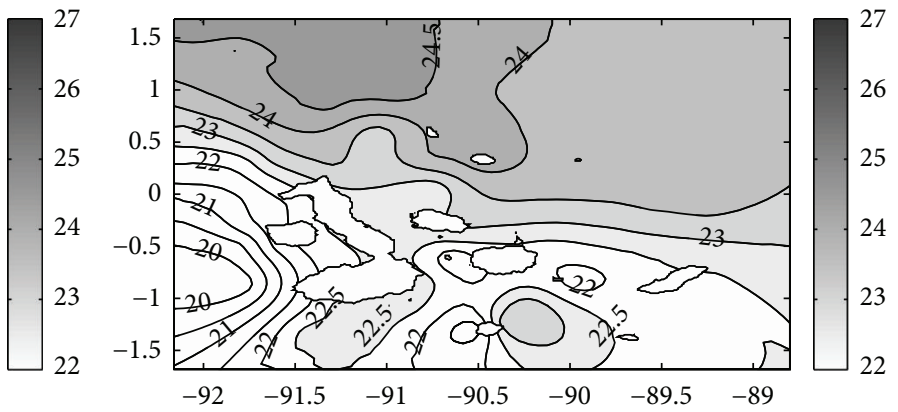

(b) Nov/Dec 2005
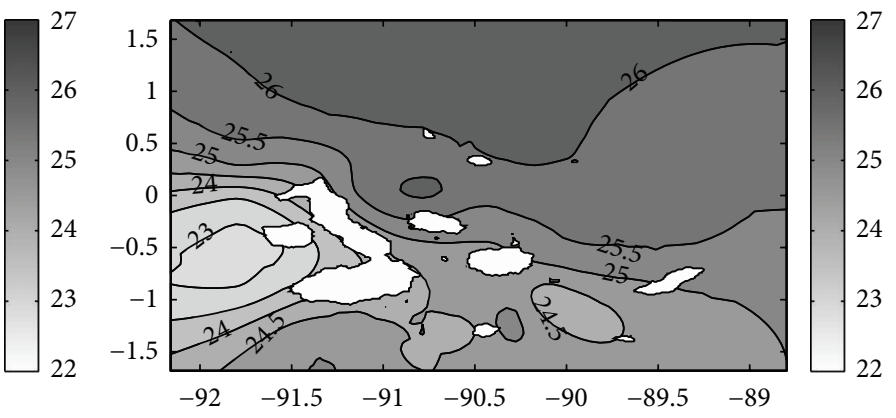

(d) Nov 2006

Figure 10: The observed sea surface temperature for (a) March 2005, (b) November/December 2005, (c) June/July 2006, and (d) November 2006 cruises. 


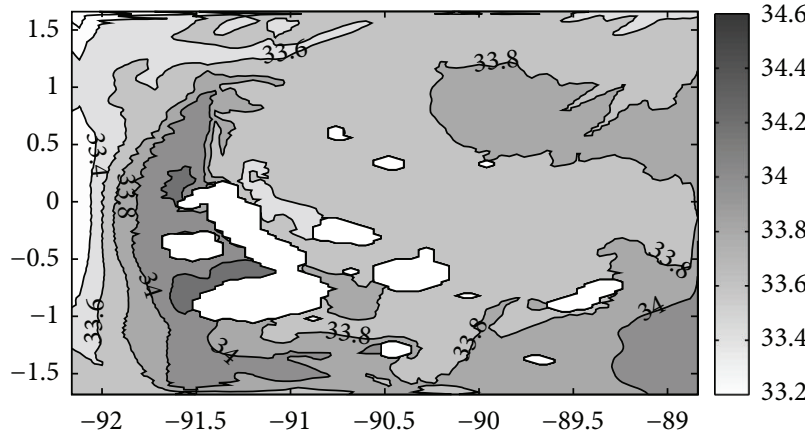

(a) Mar 2005

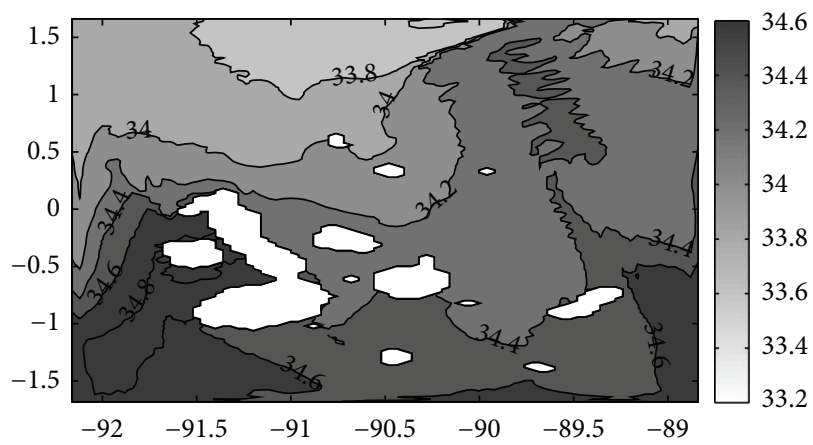

(c) Jun/Jul 2006

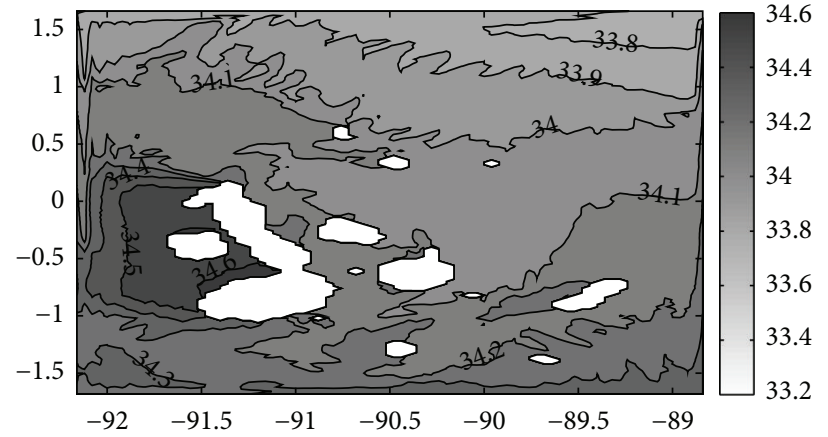

(b) Nov/Dec 2005

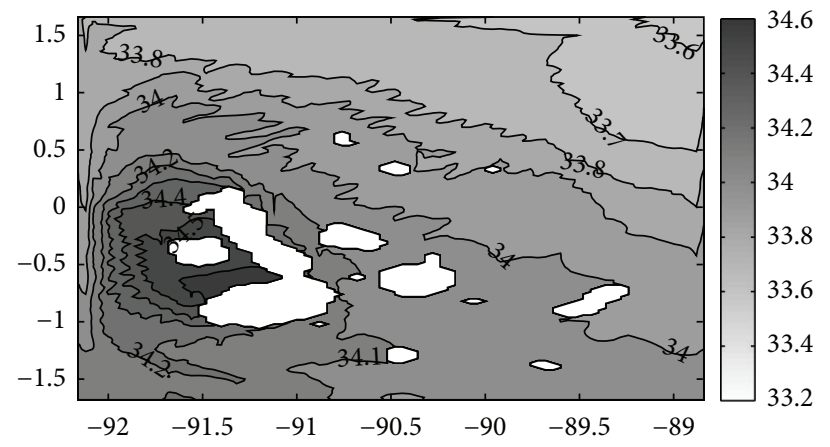

(d) Nov 2006

FIGURE 11: HYCOM simulated sea surface salinity for (a) March 2005, (b) November/December 2005, (c) June/July 2006, and (d) November 2006.

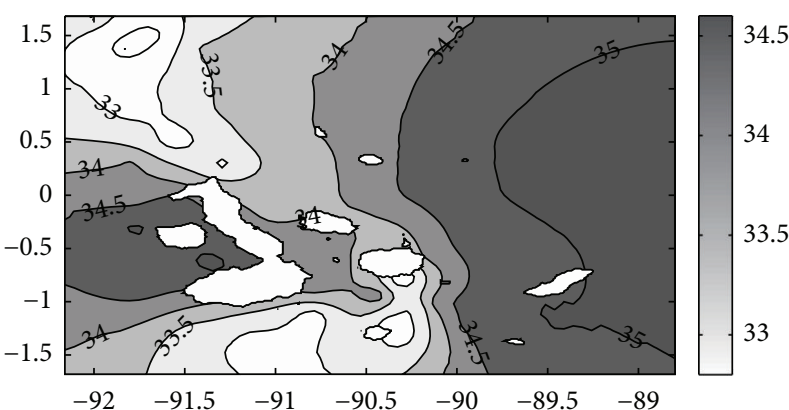

(a) Mar 2005

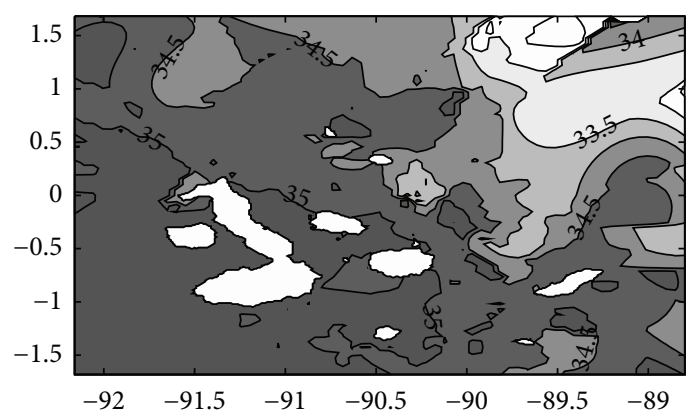

(c) Jun/Jul 2006

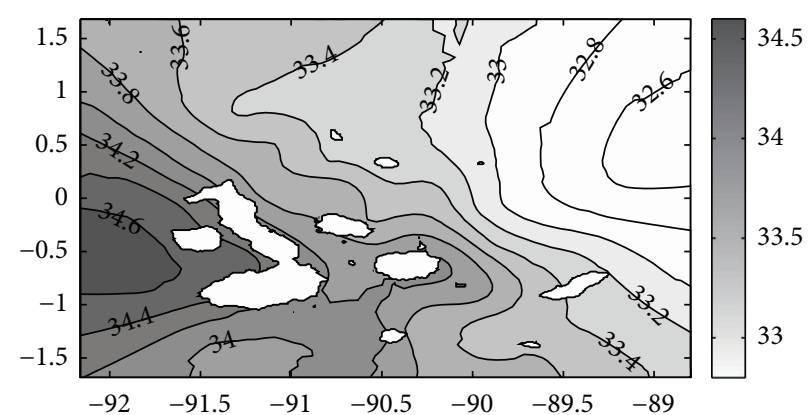

(b) Nov/Dec 2005

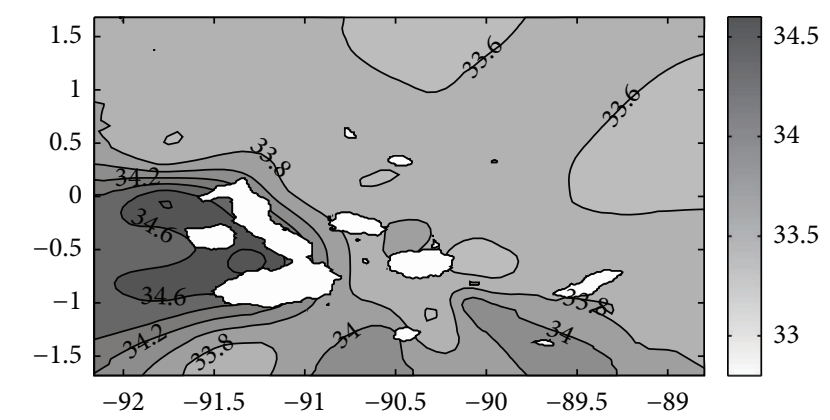

(d) Nov 2006

Figure 12: The observed sea surface salinity for (a) March 2005, (b) November/December 2005, (c) June/July 2006, and (d) November 2006 cruises. 


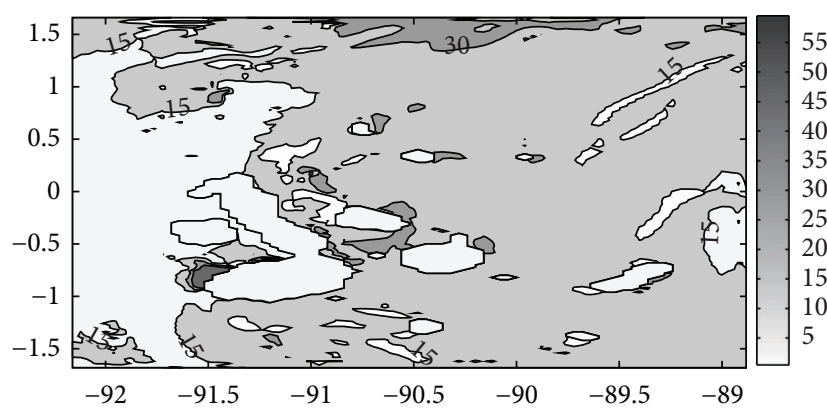

(a) Mar 2005

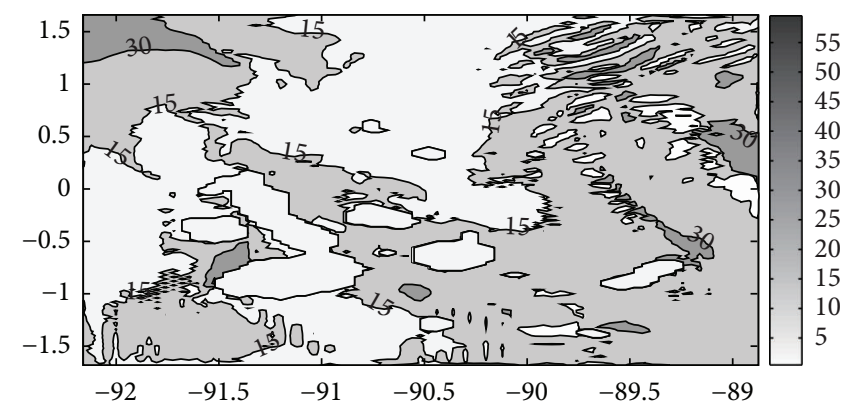

(c) Jun/Jul 2006

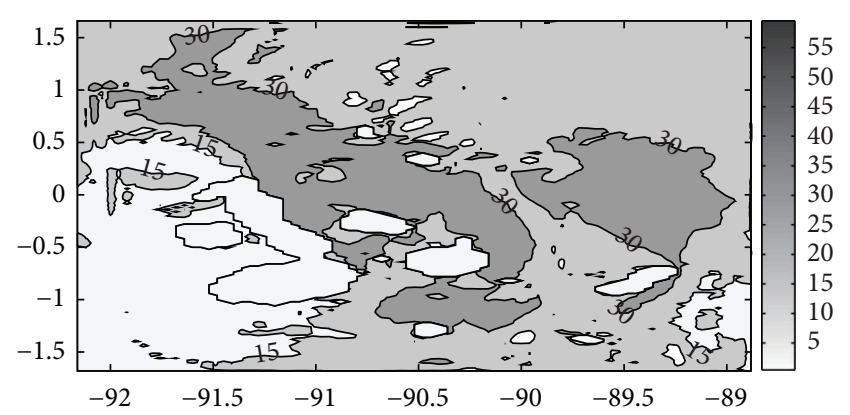

(b) Nov/Dec 2005

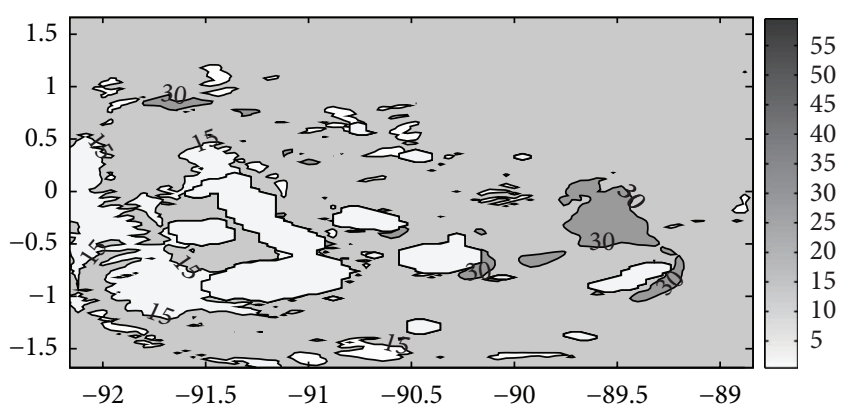

(d) Nov 2006

Figure 13: HYCOM simulated mixed layer depth for (a) March 2005, (b)November/December 2005, (c) June/July 2006, and (d) November 2006.

salinity, 35.0, in areas of the coldest waters in west of Isabella and Fernandina Islands (Figure 11(c)). The model generally simulated the main T-S characteristics observed around the Galápagos Archipelago (see Figures 10(c) and 12(c)). The modeled MLD (Figure 13(c)) shoaled to $\sim 20 \mathrm{~m}$ in west of Isabella Island and was the deepest at about $65 \mathrm{~m}$ to the north of the archipelago. The simulated SSS has higher values which in general corresponded to lower temperatures (Figures 9(c) and 11(c)). The freshest waters (33.8) were found towards the northeast and steadily increased to the southwest, reaching a maximum (34.9) in the west of Isabella Island where the observed chlorophyll a concentrations (Figure 14(c)) also reached the maximum compared with the other cruises.

The model results also indicated that surface expression of the EUC (Figure 15(c)) was quite similar to those of March 2005 , with a strong velocity core $(100 \mathrm{~cm} / \mathrm{s})$ centered just below the mixed layer. During this period, the EUC rose close to the surface and drove an eastward surface flow through the GMR. The eastward EUC (Figure 16(c)) reached up to $\sim 20 \mathrm{~m}$ in depth beneath the westward SEC.

(d) November 2006. The November 2006 cruise occurred at the end of the Garúa season and at the beginning of a mild El Niño (Figure 8). During this period, the model mean surface temperature was $25.9 \pm 1.67^{\circ} \mathrm{C}$ throughout the GMR (Figure $9(\mathrm{~d}))$. The warmest waters $\left(27.0^{\circ} \mathrm{C}\right.$ ) were in north of the archipelago and the coldest waters $\left(24.2^{\circ} \mathrm{C}\right)$ in west of Isabella and Fernandina Islands. The mean SST was 33.5 with the freshest waters found in northeast of the archipelago, forming an increasing westward salinity gradient with the highest salinity (34.6) in west of Isabella Island (Figures 9(d) and $11(\mathrm{~d}))$. Because this period was during the onset of an El Niño event, the MLD (Figure 13(d)) was the deepest and warmest during this period in the west of Isabella Island. These results were consistent with the cruise observation results (see Figures 10(d) and 12(d)). In addition, the observed chlorophyll $a$ concentrations (Figure 14(d)) around the GMR were greatly reduced during this period of reduced upwelling. The maximum observed chlorophyll $a\left(1.17 \mathrm{mg} \mathrm{m}^{-3}\right)$ was in south of Santa Cruz Island and north of Floreana and Española Islands, and minimum chlorophyll $a\left(0.17 \mathrm{mg} \mathrm{m}^{-3}\right)$ observed directly in northwest of Isabella Island. The surface currents (Figure 15(d)) during this period were dominated by the westward flowing SEC. The EUC (Figure 16(d)) was greatly weakened, leading to weaker upwelling to the west of Isabella Island.

\section{Four Cruises Comparison and Discussions}

The March 2005 cruise occurred during the wet season, a period characterized by warm SST and near the lateset stages of the weak 2004-05 El Niño. During this period, warmer waters from the Panama Current were being advected southward and the southeast trade winds weakened (characteristic of an El Niño period). The region in west of Isabella and Fernandina was characterized by the coolest and the saltiest waters observed, indicative of the productive zone upwelling of the EUC and of the reestablishment of the EUC with the end of El Niño conditions. The simulated surface flow (Figure 15(a)) showed that the eastward flow of the EUC collided with the westward flow of the SEC in both north 


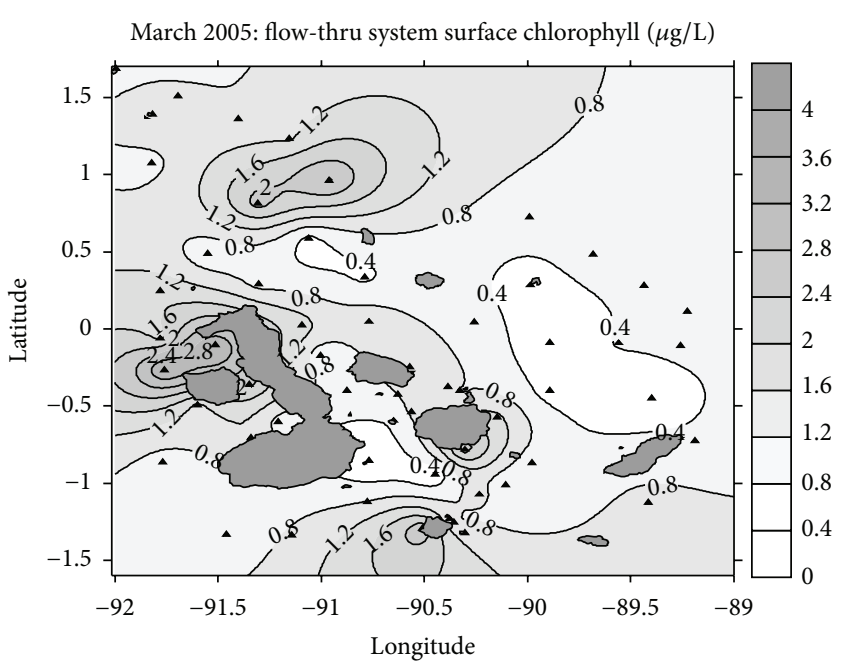

(a)

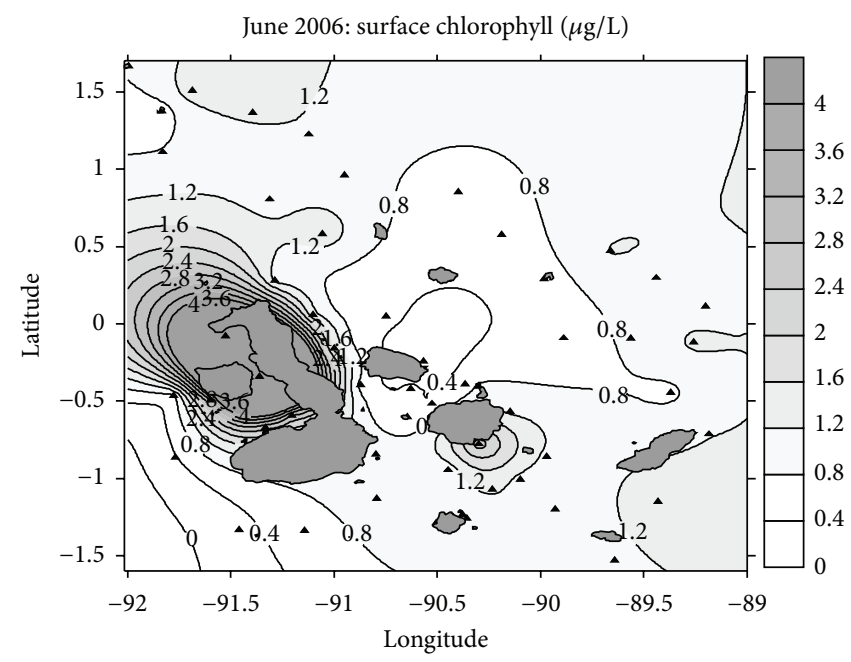

(c)

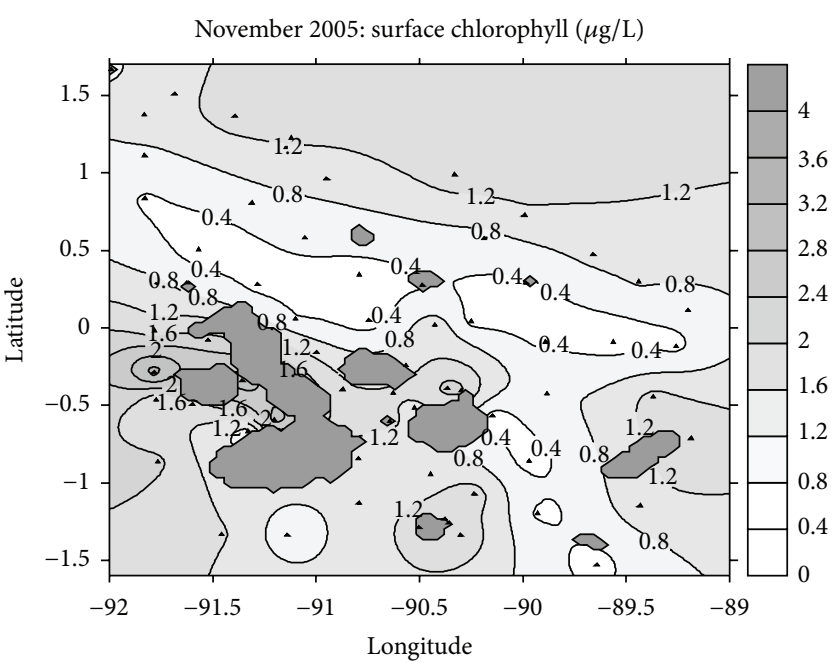

(b)

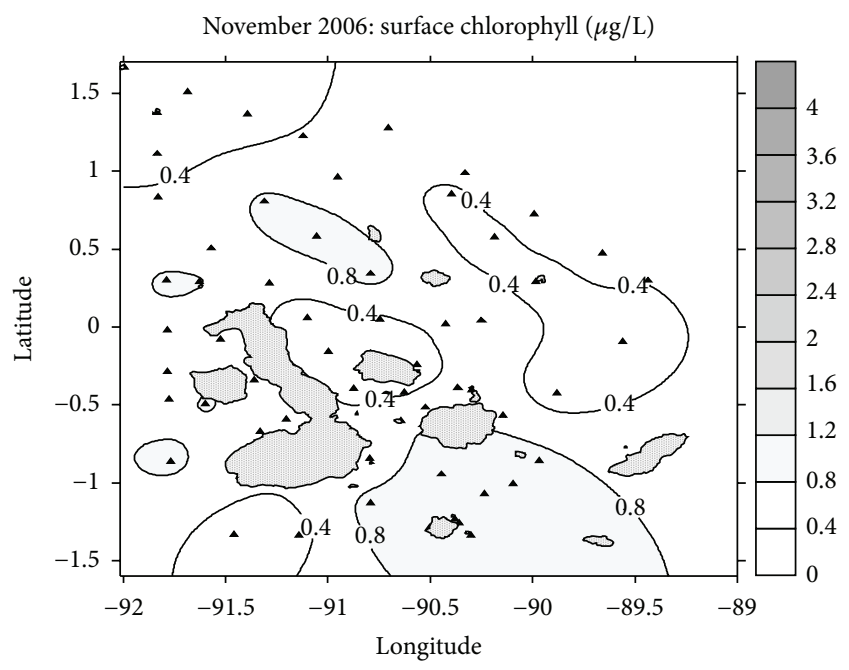

(d)

Figure 14: Chlorophyll for (a) March 2005, (b) November/December 2005, (c) June/July 2006, and (d) November 2006. The unit is mg m ${ }^{-3}$.

and south of Isabella Island. Near the archipelago, the SEC splintered into northward and southward lobes that continued to the west with a few degrees off of the equator. The November/December 2005 cruise occurred during a transition from the Garúa to the wet season with the lowest SST compared with the other three cruise periods. The modeled coldest and saltiest water was found in the west of Isabella Island and north of Fernandina Island, corresponded with the largest upwelling zone observed during 2005-2006. The modeled surface layer flow (Figure 15(b)) was completely dominated by the westward flow of the SEC throughout the GMR during this period. The EUC was relatively weak and even diminished. The June 2006 cruise occurred during a transition period, leaving the wet season and entering the Garúa characterized by a strengthening of the southeast trade winds. The EUC characteristics (Figure 15(c)) are similar to those of March 2005 (see Figure 15(a)) and the EUC core was centered near the mixed layer and extends to the surface and drives a warm eastward flow through the GMR. The coldest and the saltiest waters were found in the west of Isabella and Fernandina Islands and were associated with the highest chlorophyll concentration and the most productive upwelling zone during this time of the year (Figure 14(c)). Model results also indicated that the eastward EUC existed $\sim 20 \mathrm{~m}$ above the thermocline, beneath the westward SEC. During this period, the mixed layer depth was the shallowest throughout the archipelago compared with other cruises periods. The November 2006 cruise occurred at the end of the Garúa and at the beginning of a mild El Niño. This transition was also characterized by weaker upwelling to the west of Isabella Island associated with a weakening of the EUC. The thermocline was the deepest and the warmest during the November 2006 cruise in west of Isabella Island. The chlorophyll $a$ around the GMR was greatly reduced. The model results are in good agreement with observations. All four cruises had warm, fresher water 


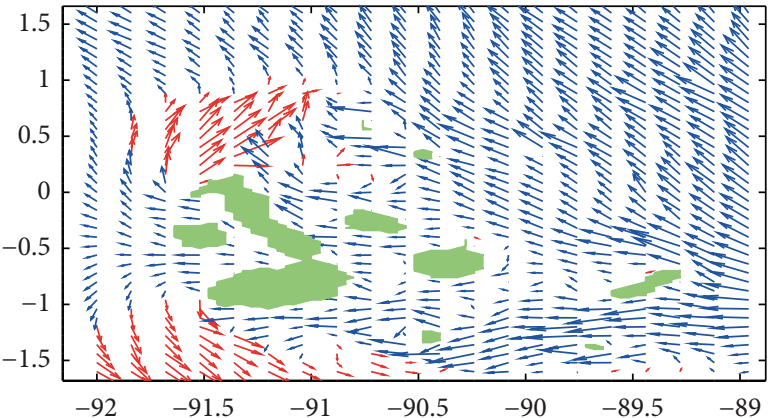

(a) Mar 2005

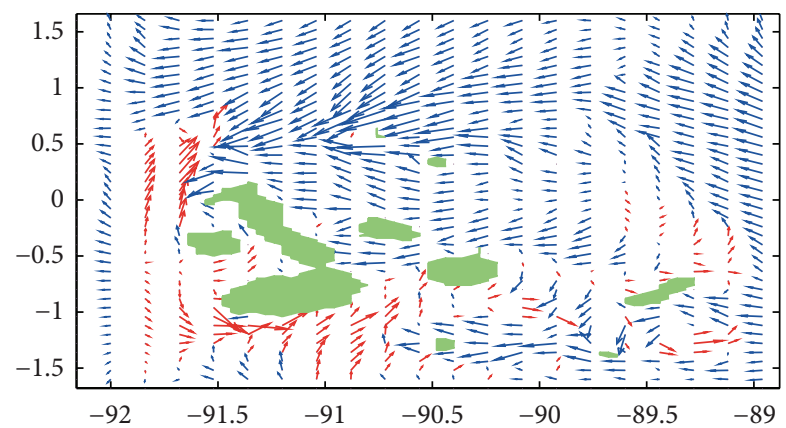

(c) Jun/Jul 2006

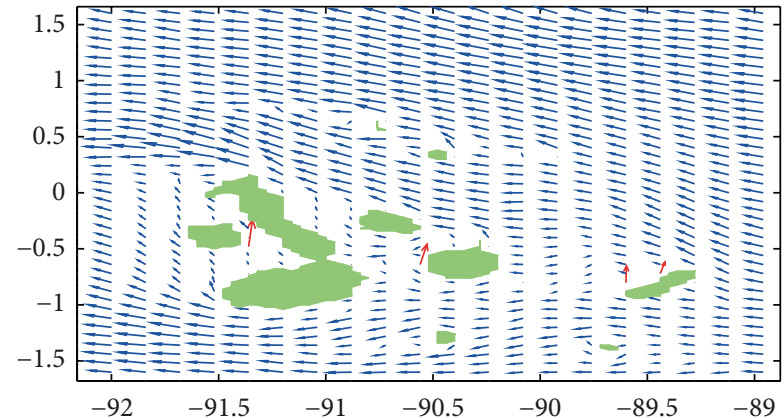

(b) Nov/Dec 2005

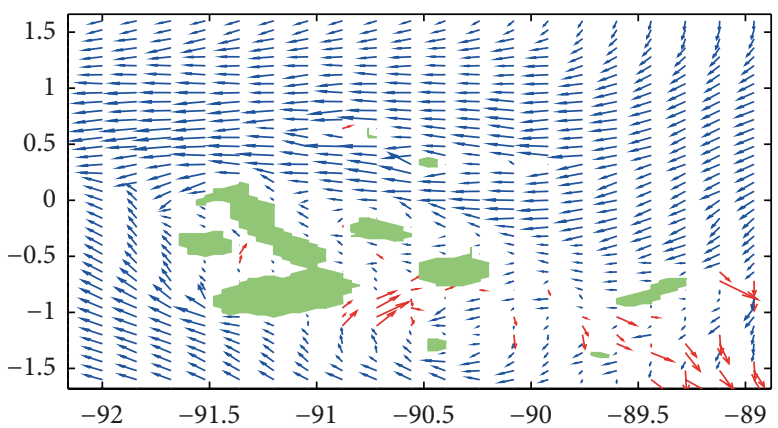

(d) Nov 2006

FIGURE 15: Hydrodynamic model surface layer flow of the SEC and EUC throughout the GMR for (a) March 2005, (b) November/December 2005, (c) June/July 2006, and (d) November 2006. Blue arrows represent the westward current, while the red arrows represent eastward current. The unit is $\mathrm{m} \mathrm{s}^{-1}$.

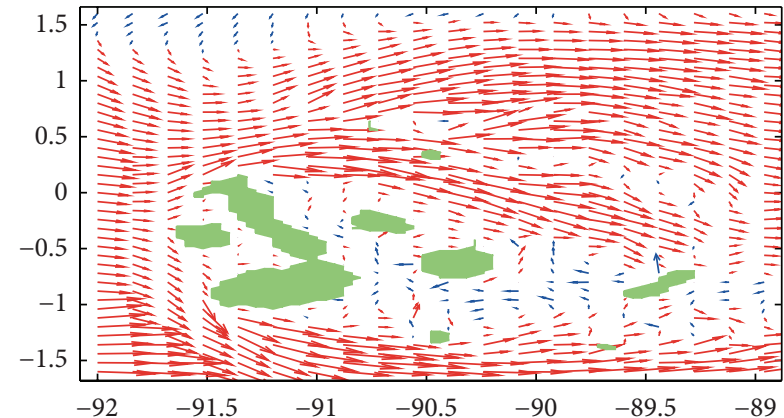

(a) Mar 2005

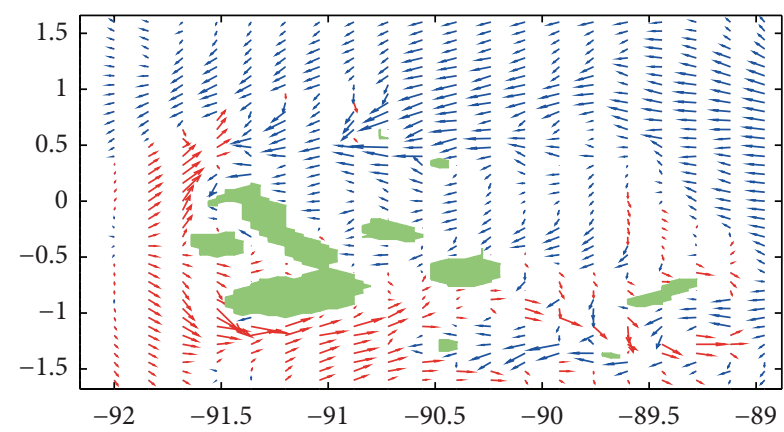

(c) Jun/Jul 2006

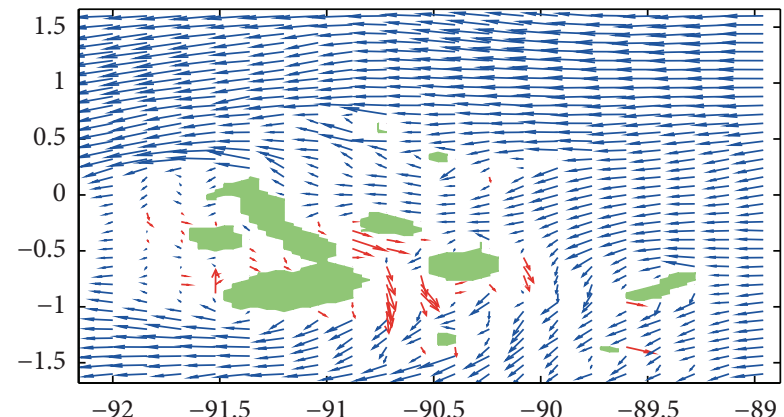

(b) Nov/Dec 2005

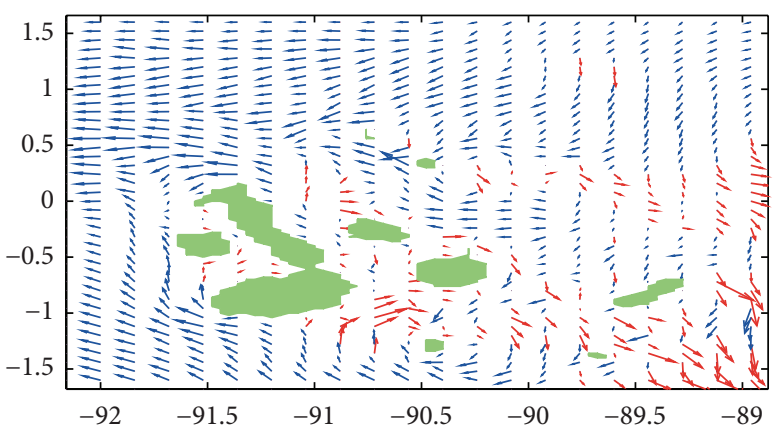

(d) Nov 2006

FIGURE 16: Hydrodynamic model mix layer flow of the SEC and EUC throughout the GMR for (a) March 2005, (b) November/December 2005, (c) June/July 2006, and (d) November 2006. Blue arrows represent the westward current, while the red arrows represent eastward current. The unit is $\mathrm{m} \mathrm{s}^{-1}$. 
in the east part of the GMR supplied by the SEC, with the relative cold and salty water in west of Isabella Island indicating the productive upwelling zone [8]. A gradient was formed from east to west with increasing salinity and decreasing temperature. According to Liu et al. ([24], Figure $20)$, the simulated EUC/SEC volume transport at $140^{\circ} \mathrm{W}$ and $110^{\circ} \mathrm{W}$ is consistent with the constructed EUC/SEC volume transport obtained from the in situ CTD/ADCP data during the Tropical Atmosphere-Ocean/Triangle Trans-Ocean Buoy Network (TAO/TRITON) buoy array cruises from 2001 to 2006. In the future, more current observation is needed to further compare and validate our model results.

\section{Summary}

This paper focuses on the oceanographic variability and physical settings associated with the biological productivity and biogeography of the various marine ecosystems across the GMR using a general ocean circulation model (HYCOM). A four-level nested-domain ocean system is used in the study. The model results were compared with data taken during oceanographic cruises in 2005/2006. Daily surface fields obtained from the NCEP and the wind forcing from QuikSCAT were used to drive the simulations. Sensitivity to different surface forcing conditions as well as different resolutions was examined. Sensitivity tests showed that frequency of wind forcing higher than weekly average is more reliable than monthly forcing in reproducing the observed oceanic features within the GMR. In a controlled experiment where the atmospheric forcing frequency was reduced from daily to monthly, the results simulated by the ocean model are shown to be less accurate than those simulated using daily forcing. The simulation around the GMR is greatly improved with the increase of horizontal resolutions. The simulation with the resolution of $0.04^{\circ}$ can depict the intraseasonal signal from the tropical instability waves (TIW) [34], as well as the annual and the interannual signals, whereas the lowresolution global model failed to depict TIW signal. Results indicate that with prescribed atmospheric forcing from 1950 to 2007 the major characteristics of the ocean circulation and its variability in the Galápagos region, including the ENSO events, annual, and seasonal cycles, upwelling system, local and regional current systems, and tropical instability waves, can be reproduced by the nested HYCOM. There is a high correlation between the simulated SST anomalies and the observed SST anomalies in the Niño3.4 region.

The archipelago has a large range in temperature and salinity associated with four different current systems and topographically and wind forced upwelling. West of Isabella and Fernandina Islands are the largest and the most consistent upwelling zones, resulting from the collision of the Equatorial Undercurrent with the islands, bringing relatively colder and salty waters to the surface, and marking the location of high biological production at the surface with the EUC shoaling to approximately $20 \mathrm{~m}$ from its normal depth of $50 \mathrm{~m}$ just to the west of the islands. The EUC collides with the islands and breaks into a number of well-defined flows through the islands. Model results show that the EUC is the strongest during the late spring/early summer and weakened in the late fall. The collapse of the westerlies with the onset of El Niño event in 2006 resulted in a collapse of the EUC flow in the vicinity of the Galápagos and effectively shut off the major upwelling regions. The property distributions in the far northern region of the GMR are characterized by warmer, fresher water and had the deepest mixed layer depth as a result of Panama Current waters from the northeast. The water masses over the remainder of the region result from mixing of cool Peru Current waters and upwelled Cold Tongue waters entering from the east to the southeast mixing with the upwelled EUC waters.

This work will have a contribution to the field of dynamical downscaling for ocean circulations and will serve as a basis for studying of how climate change affects marginal areas that are not well resolved by coarse-resolution climate models. Finally, it is important to point out some of the limitations in this study. Here, our model results mainly focused on the ocean circulation in the GMR, which do not account for the tidal influence. The inclusion of tides is also important for future study since the dynamics within the islands are essentially the same as those in a coastal environment; therefore, the tides can have important implications regarding larval dispersal [35]. Besides, data assimilation has not been used in this study. Data assimilation, which consists in combining available data with a dynamical model to provide an efficient and accurate estimate of the underlying state of the system, is now recognized as the most powerful tool to improve the consistency between the model and data [36]. There is an ongoing effort to add data assimilation to HYCOM (HYCOM Consortium for Data Assimilation Modeling, http://hycom.org/data-assimilation). Thus, further work needs to be done to improve the simulation accuracy by assimilating available observations into model. Further research is also required on the ecosystembased responses to climate changes in the GMR [24]. Here, we used surface-forced ocean model to study the ocean circulation around the GMR. The coupled models should be used to conduct those studies [37]. This study will also benefit from the development of regional coupled atmosphere-ocean models [38].

\section{Conflict of Interests}

The authors declare that there is no conflict of interests regarding the publication of this paper.

\section{Acknowledgments}

The authors would like to thank Dr. Lakshmi Kantha and the anonymous reviewers for their thoughtful comments and suggestions, which led to a significant improvement of the paper. This project was funded by National Aeronautics Space Association (NASA) Biodiversity and Ecological Forecasting Grant NNG04GL98G. The Counterpart US-AID no. 518-A00-03-00152-00 and UK Darwin Initiative Project no. 14048 also provided funding for this project. All modeling work is carried out in the Coastal Fluid Dynamical Lab of 
North Carolina State University using the High-Performance Computing (HPC) system.

\section{References}

[1] R. Bustamante, K. J. Collins, and R. Bensted-Smith, "Biodiversity conservation in the Galápagos Marine Reserve," Entomologie, vol. 68, pp. 45-52, 1999.

[2] S. Jennings, A. S. Brierley, and J. W. Walker, "The inshore fish assemblages of the Galapagos archipelago," Biological Conservation, vol. 70, no. 1, pp. 49-57, 1994.

[3] M. R. Stevenson and B. A. Taft, "New evidence of Equatorial Undercurrent east of the Galápagos Islands," Journal of Marine Research, vol. 29, pp. 103-115, 1971.

[4] J. A. Knauss, "Further measurements and observations of the Cromwell Current," Journal of Marine Research, vol. 24, pp. 205240,1966

[5] K. B. Karnauskas, R. Murtugudde, and A. J. Busalacchi, "The effect of the Galápagos Islands on the equatorial Pacific cold tongue," Journal of Physical Oceanography, vol. 37, no. 5, pp. 1266-1281, 2007.

[6] N. Jr. Christensen, "Observations of the Cromwell current near the Galápagos Islands,” Deep-Sea Research, vol. 18, no. 1, pp. 2733, 1971.

[7] J. M. Steger, C. A. Collins, and P. C. Chu, "Circulation in the Archipielago de Colon (Galapagos Islands), November, 1993," Deep-Sea Research, vol. 45, no. 6, pp. 1093-1114, 1998.

[8] G. T. Houvenaghel, "Oceanographic setting of the Galápagos Islands," in Key Environments: Galápagos, R. Perry, Ed., pp. 4354, Pergamon Press, Oxford, UK, 1984.

[9] G. Feldman, D. Clark, and D. Halpern, "Satellite color observations of the phytoplankton distribution in the eastern equatorial pacific during the 1982-1983 El Niño," Science, vol. 226, no. 4678, pp. 1069-1071, 1984.

[10] G. Feldman, "Patterns of phytoplankton production around the Galápagos Islands," in Tidal Mixing and Plankton Dynamics, M. J. Bowman, R. T. Barber, and C. N. K. Mooers, Eds., Lecture Notes on Coastal and Esutarine Studies, pp. 77-106, Springer, Berlin, Germany, 1986.

[11] S. P. Hayes, "Sea Level and Near Surface Temperature Variability at the Galapagos Islands, 1979-83," in El Niño en Las IsLas Galápagos: El Evento de 1982-1983, pp. 49-81, Fundación Charles Darwin para los Islas Galápagos, Quito, Ecuador, 1985.

[12] D. M. Palacios, "Seasonal patterns of sea-surface temperature and ocean color around the Galápagos: regional and local influences," Deep-Sea Research, vol. 51, no. 1-3, pp. 43-57, 2004.

[13] P. W. Glynn and J. S. Ault, "A biogeographic analysis and review of the far eastern Pacific coral reef region," Coral Reefs, vol. 19, no. 1, pp. 1-23, 2000.

[14] M. A. Riedinger, M. Steinitz-Kannan, W. M. Last, and M. Brenner, "A 6100 14C yr record of El Niño activity from the Galápagos Islands," Journal of Paleolimnology, vol. 27, no. 1, pp. $1-7,2002$.

[15] D. T. Rodbell, G. O. Seltzer, D. M. Anderson, M. B. Abbott, D. B. Enfield, and J. H. Newman, "An asymptotically equal to 15,000Year Record of El Niño-Driven Alluviation in Southwestern Ecuador," Science, vol. 283, no. 5401, pp. 516-519, 1999.

[16] F. P. Chavez, P. G. Strutton, G. E. Friederich et al., "Biological and chemical response of the equatorial Pacific Ocean to the 1997-98 El Nino," Science, vol. 286, no. 5447, pp. 2126-2131, 1999.
[17] S. J. Brentnall, The impact of the Galápagos Islands on the dynamics of the equatorial east Pacific [Ph.D. thesis], University of Southampton, Southampton, UK, 1999.

[18] C. Eden and A. Timmerman, “The influence of the Galápagos Islands on tropical temperatures, currents and the generation of tropical instability waves," Geophysical Research Letters, vol. 31, no. 15, Article ID L15308, 2004.

[19] S. Cravatte, G. Madec, T. Izumo, C. Menkes, and A. Bozec, "Progress in the 3-D circulation of the eastern equatorial Pacific in a climate ocean model," Ocean Modelling, vol. 17, no. 1, pp. 2848, 2007.

[20] K. B. Karnauskas, G. C. Johnson, and R. Murtugudde, "An equatorial ocean bottleneck in global climate models," Journal of Climate, vol. 25, no. 1, pp. 343-349, 2012.

[21] R. Bleck, "An oceanic general circulation model framed in hybrid isopycnic-Cartesian coordinates," Ocean Modelling, vol. 4, no. 1, pp. 55-88, 2002.

[22] E. P. Chassignet, L. T. Smith, G. R. Halliwell, and R. Bleck, "North Atlantic Simulations with the Hybrid Coordinate Ocean Model (HYCOM): impact of the vertical coordinate choice, reference density, and thermobaricity," Journal of Physical Oceanography, vol. 33, pp. 2504-2526, 2003.

[23] G. R. Halliwell, "Evaluation of vertical coordinate and vertical mixing algorithms in the HYbrid-Coordinate Ocean Model (HYCOM)," Ocean Modelling, vol. 7, no. 3-4, pp. 285-322, 2004.

[24] Y. Liu, L. Xie, J. M. Morrison, and D. Kamykowski, "Dynamic downscaling of the impact of climate change on the ocean circulation in the Galapagos Archipelago," Advances in Meteorology, vol. 2013, Article ID 837432, 18 pages, 2013.

[25] S. Levitus and T. Boyer, "World Ocean Atlas 1994, Volume 4: Temperature," NOAA Atlas NESDIS 4, US Department of Commerce, Washington, DC, USA, 1994.

[26] S. Levitus, R. Burgett, and T. Boyer, "World Ocean Atlas 1994, Volume 3: Salinity," NOAA Atlas NESDIS 3, US Department of Commerce, Washington, DC, USA, 1994.

[27] R. Kistler, E. Kalnay, W. Collins et al., "The NCEP-NCAR 50year reanalysis: monthly means CD-ROM and documentation," Bulletin of the American Meteorological Society, vol. 82, no. 2, pp. 247-267, 2001.

[28] D. R. Cayan, "Latent and sensible heat flux anomalies over the northern oceans: driving the sea surface temperature," Journal of Physical Oceanography, vol. 22, no. 8, pp. 859-881, 1992.

[29] D. Cayan, "Latent and sensible heat flux anomalies over the northern ocean: the connection to monthly atmospheric circulation," Journal of Climate, vol. 5, pp. 354-369, 1992.

[30] W. G. Large, J. C. McWilliams, and S. C. Doney, "Oceanic vertical mixing: a review and a model with a nonlocal boundary layer parameterization," Reviews of Geophysics, vol. 32, no. 4, pp. 363-403, 1994.

[31] K. E. Trenberth, "The Definition of El Niño," Bulletin of the American Meteorological Society, vol. 78, no. 12, pp. 2771-2777, 1997.

[32] B. A. Schaeffer, J. M. Morrison, D. Kamykowski et al., "Phytoplankton biomass distribution and identification of productive habitats within the Galapagos Marine Reserve by MODIS, a surface acquisition system, and in-situ measurements," Remote Sensing of Environment, vol. 112, no. 6, pp. 3044-3054, 2008.

[33] K. Wyrtki and B. Kilonsky, "Mean water and current structure during the Hawaii-to-Tahiti shuttle experiment," Journal of Physical Oceanography, vol. 14, pp. 242-254, 1984. 
[34] W. V. Sweet, J. M. Morrison, Y. Liu et al., “Tropical instability wave interactions within the Galápagos Archipelago," Deep-Sea Research, vol. 56, no. 8, pp. 1217-1229, 2009.

[35] E. Wolanski and S. Spagnol, "Environmental degradation by mud in tropical estuaries," Regional Environmental Change, vol. 1, no. 3-4, pp. 152-162, 2000.

[36] M. Ghil and P. Malanotte-Rizzoli, "Data assimilation in meteorology and oceanography," Advances in Geophysics, vol. 33, pp. 141-266, 1991.

[37] K. B. Karnauskas, R. Murtugudde, and A. J. Busalacchi, “The effect of the Galápagos Islands on ENSO in forced ocean and hybrid coupled models," Journal of Physical Oceanography, vol. 38, no. 11, pp. 2519-2534, 2008.

[38] R. J. Small, T. Campbell, J. Teixeira et al., "Air-sea interaction in the Ligurian sea: assessment of a coupled ocean-atmosphere model using in situ data from LASIE07," Monthly Weather Review, vol. 139, no. 6, pp. 1785-1808, 2011. 

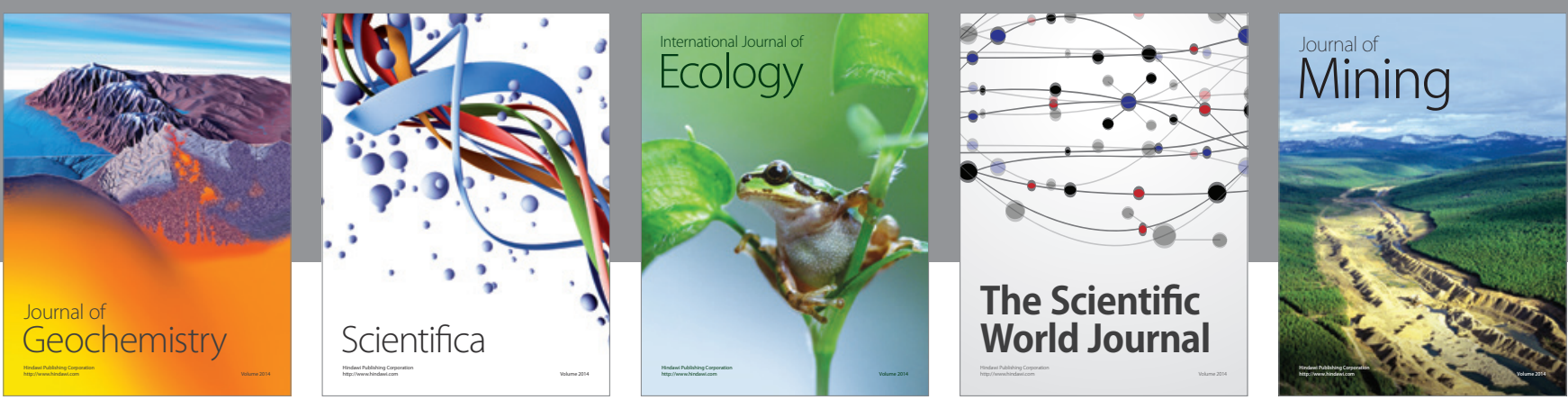

The Scientific World Journal
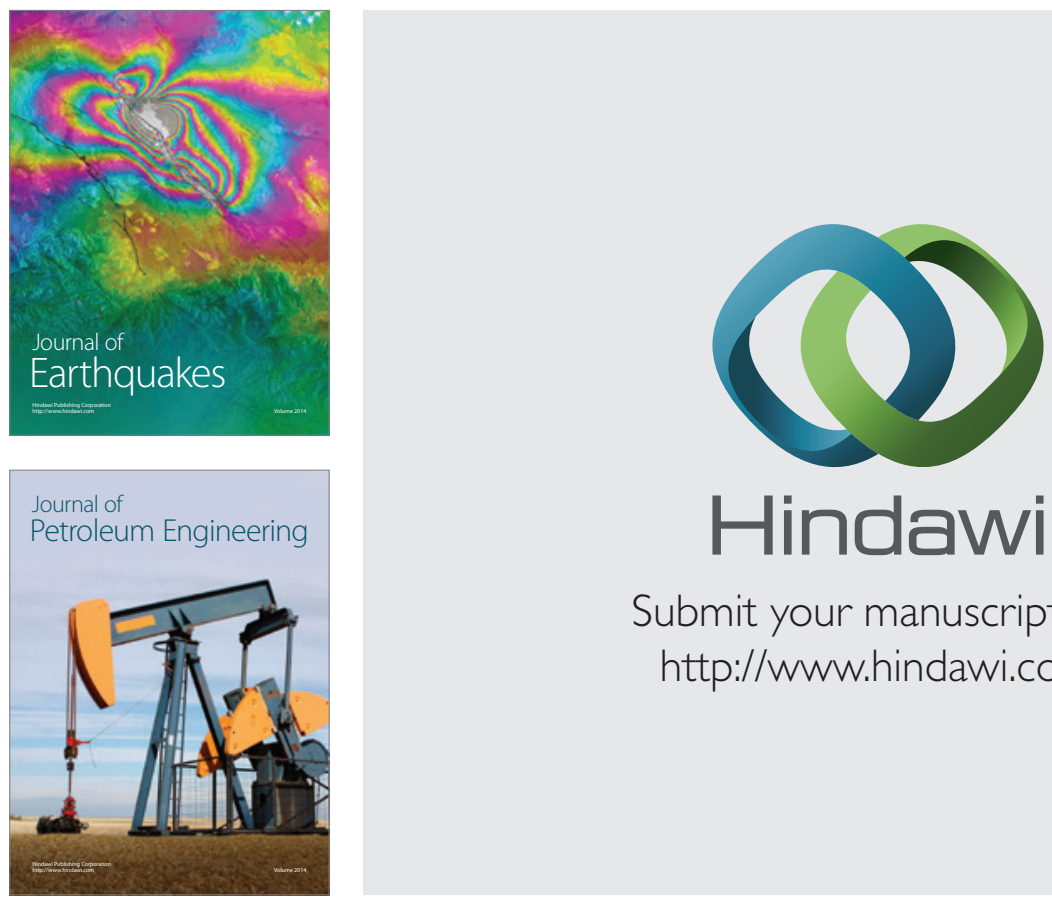

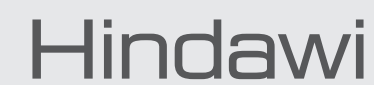

Submit your manuscripts at

http://www.hindawi.com
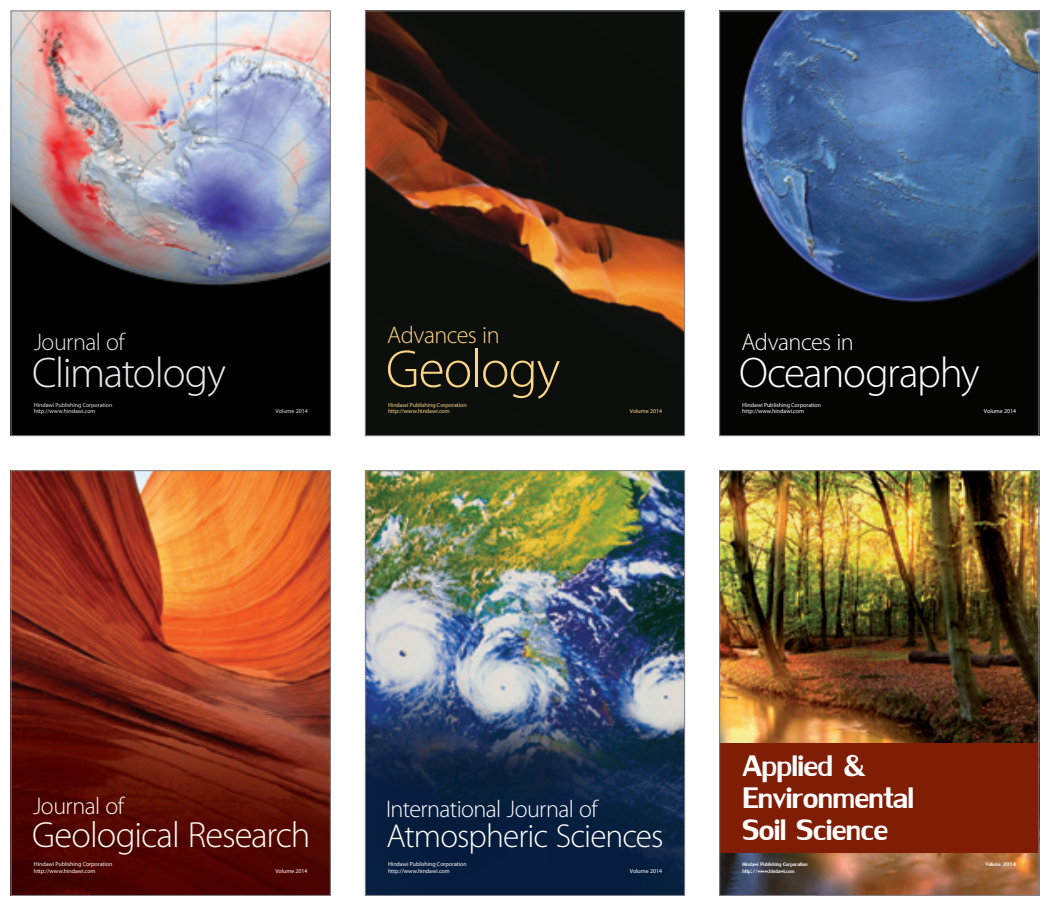
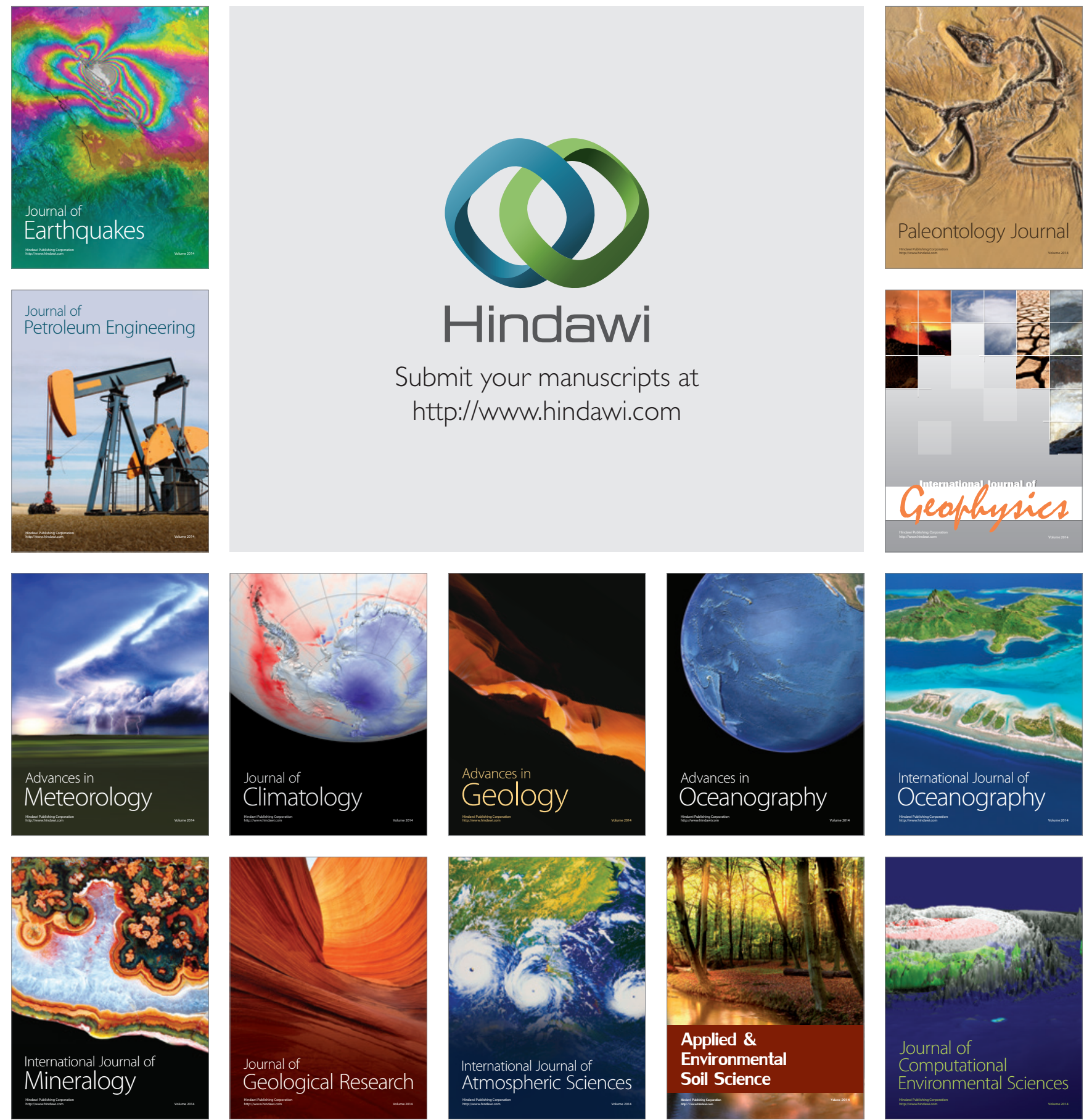